\title{
3D Geologic Framework for Use with the U.S. Geological Survey National Crustal Model, Phase 1-Western United States
}

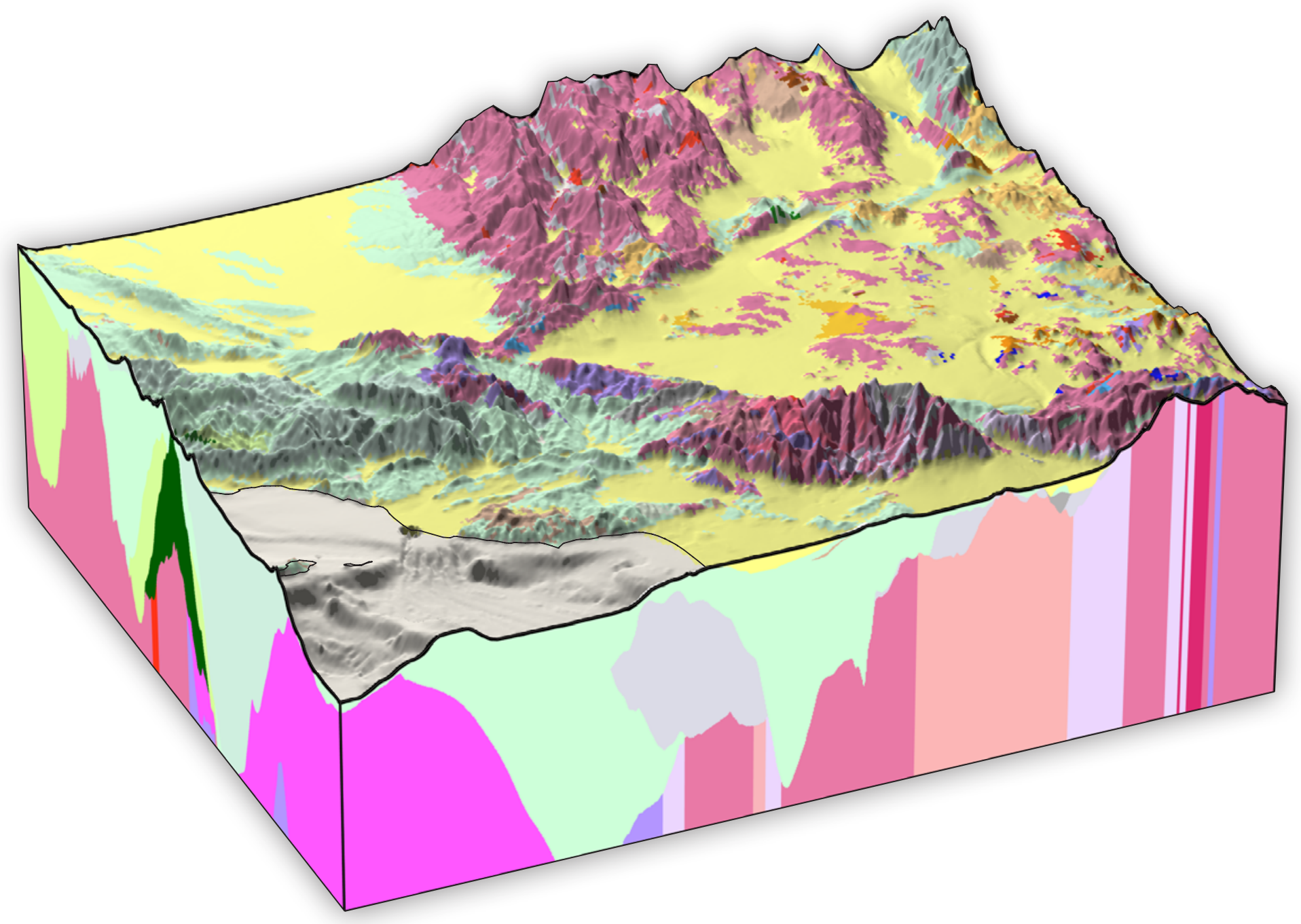

Open-File Report 2019-1081

Version 1.1, December 2019 
Cover. Geologic cross sections through the geologic framework model in southern California. Unconsolidated materials in the valleys lie above Cenozoic and Mesozoic sandstones and other sedimentary rocks, which sit on top of igneous intrusions that extend vertically and have significant uncertainty in subsurface distribution. In many mountainous areas, igneous rocks are present at the surface. 


\section{D Geologic Framework for Use with the U.S. Geological Survey National Crustal Model, Phase 1-Western United States}

By Oliver S. Boyd

Open-File Report 2019-1081

Version 1.1, December 2019 


\title{
U.S. Department of the Interior DAVID BERNHARDT, Secretary
}

\section{U.S. Geological Survey James F. Reilly II, Director}

\author{
U.S. Geological Survey, Reston, Virginia: \\ First release: 2019 \\ Revised: December 2019 (ver 1.1)
}

\begin{abstract}
For more information on the USGS - the Federal source for science about the Earth, its natural and living resources, natural hazards, and the environment-visit https://www.usgs.gov or call 1-888-ASK-USGS.

For an overview of USGS information products, including maps, imagery, and publications, visit https://store.usgs.gov.
\end{abstract}

Any use of trade, firm, or product names is for descriptive purposes only and does not imply endorsement by the U.S. Government.

Although this information product, for the most part, is in the public domain, it also may contain copyrighted materials as noted in the text. Permission to reproduce copyrighted items must be secured from the copyright owner.

Suggested citation:

Boyd, O.S., 2019, 3D Geologic framework for use with the U.S. Geological Survey National Crustal Model, Phase 1—Western United States (ver. 1.1, December 2019): U.S. Geological Survey Open-File Report 2019-1081, 36 p., https://doi.org/10.3133/ofr20191081.

Associated data for this publication: Boyd, 0.S., 2019, 3D Geologic Framework for use with the U.S. Geological Survey National Crustal Model, Phase 1-Western United States: U.S. Geological Survey data release, https://doi.org/10.5066/P9SBQENM.

ISSN 2331-1258 (online) 


\section{Acknowledgments}

I am grateful to past and present members of the National Crustal Model advisory committee: Mike Blanpied, Sue Hoover, Will Levandowski, David Lidke, Nico Luco, Chuck Mueller, Mark Petersen, Sanaz Rezaeian, Eric Thompson, and Rob Williams, all presently or formerly at the U.S. Geological Survey (USGS). The National Seismic Hazard Mapping Steering Committee, Anjana Shah of the Geology, Geophysics, and Geochemistry Science Center, Carma San Juan of the Geology, Geophysics, and Geochemistry Center (all USGS), and many other colleagues at meetings and workshops provided critical feedback during the process of building the National

Crustal Model. In early stages of this work, before the updated State Geologic Map Compilation produced by the former Central Mineral and Environmental Resources Science Center (now Geology, Geophysics, and Geochemistry Science Center), State geologists in the western United States (U.S.) were consulted. I am indebted to Jessica Czajkowski (Washington), lan Madin (Oregon), Marc Dellatre and Rui Chen (California), Grant Willis (Utah), Mike Stickney (Montana), Erin Campbell (Wyoming), Fred Anderson (North Dakota), Jeremy Boak and Jake Walter (Oklahoma), and Alexandros Savvaidis (Texas) for providing helpful feedback that improved the 3D geologic framework. I would also like to thank Peter Schweitzer of the USGS for producing the red-green-blue lithologic color code file and Steve Angster and Don Sweetkind, both at the USGS, for their thorough reviews that significantly improved this report. This effort was funded by the USGS Earthquake Hazards Program. 


\section{Contents}

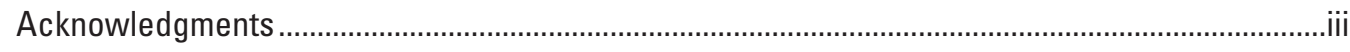

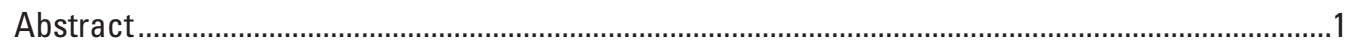

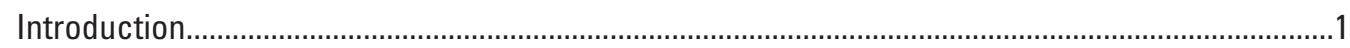

Geology and Age of Rocks at or Near the Earth's Surface ...........................................................

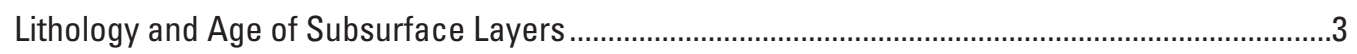

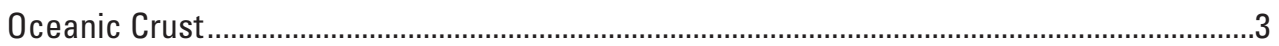

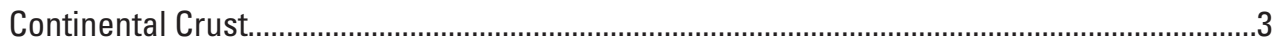

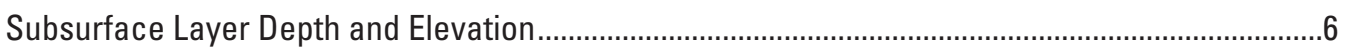

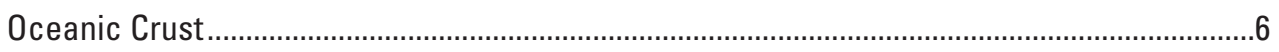

Continental Crust

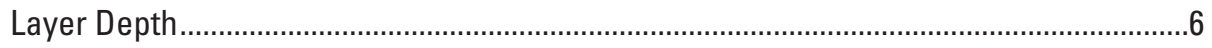

Depth to Top of Bedrock Layer ................................................................................

Depth to Top of Basement Layers .............................................................................

Depth to Top of Lower Crust and Moho ………………….....................................11

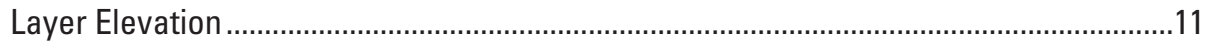

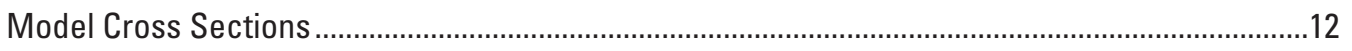

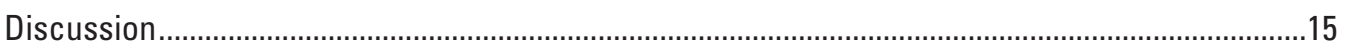

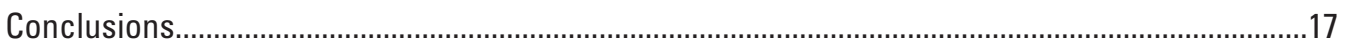

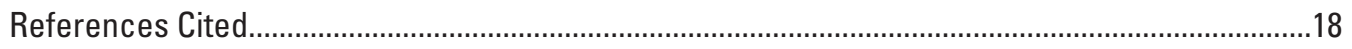

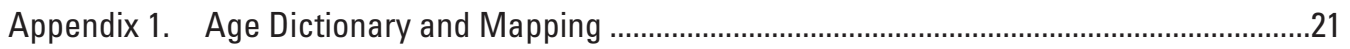

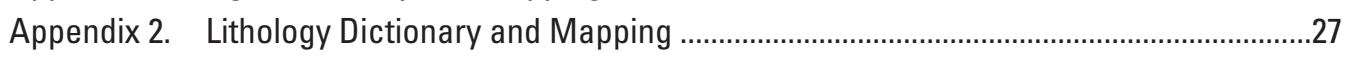

Appendix 3. Exceptions to Geologic Map Modification Rules.....................................................36 


\section{Figures}

1. Merged geologic map of the United States and southern Canada and northern Mexico, showing, in most cases, the minimum age, as derived from the minimum age fields in the Geologic Map of North America database (Garrity and Soller, 2009) and the State Geologic Map Compilation (SGMC; Horton and others, 2017; Horton, 2017)

2. Dominant mapped lithology of the United States and southern Canada and northern Mexico. Note that state maps compiled by the State Geologic Map Compilation (Horton and others, 2017; Horton, 2017) for several states around the Great Lakes show only bedrock geology, such that young glacial deposits are underrepresented on this map

3. Map of depth to bedrock. The region of the United States in Phase 1 is from Shah and Boyd (2018) with several modifications including additional datasets offshore and in Canada, Mexico, and the San Francisco Bay Area.

4. Map of thickness of Cenozoic sedimentary and extrusive volcanic rocks (SEVR). The hashed region demarcates the areas in Oregon, Washington, Idaho, northern California, the Colorado Plateau, and central North America where the closet distance to intrusive or Mesozoic and older outcrop method was used to derive Cenozoic SEVR thickness.

5. Map of thickness of Phanerozoic sedimentary and extrusive volcanic rocks (SEVR). Dashed line demarcates the hashed area outside of central North America where the closet distance to intrusive or Proterozoic and Archean outcrop method was used to derive the base of Phanerozoic SEVR.

6. Cross-section profile locations in the United States. Physiographic provinces outlined using green dashed lines are adapted from Fenneman and Johnson (1946). Blue dashed lines indicate the profile locations, from north to south, seen in figures 7 and 8 . The cross sections in figure 9 lie along the northernmost profile between $A$ and $A^{\prime}$

7. Cross-sections of subsurface age in the United States. Profile locations, from north to south, are shown in figure 6 ...

8. Cross-sections of subsurface lithology in the United States. Profile locations, from north to south, are shown in figure 6 .

9. Cross sections through Seattle, Washington, highlighting the Seattle Basin in the upper two cross sections and the subducting Juan de Fuca plate in the lower two .....16 


\section{Table}

1. Datasets used to produce bedrock and depth to the base of Cenozoic and Phanerozoic sedimentary and extrusive volcanic rocks (SEVR) surfaces in western North America

\section{Datum}

Vertical coordinate information is referenced to the World Geodetic System 1984 (WGS84).

Horizontal coordinate information is referenced to the North American Datum of 1983 (NAD 83).

Elevation, as used in this report, refers to distance above the vertical datum.

\section{Conversion Factors}

International System of Units to U.S. customary units

\begin{tabular}{lcl}
\hline \multicolumn{1}{c}{ Multiply } & By & To obtain \\
\hline & Length & \\
\hline meter $(\mathrm{m})$ & 3.281 & foot $(\mathrm{ft})$ \\
kilometer $(\mathrm{km})$ & 0.6214 & mile $(\mathrm{mi})$ \\
\hline & Velocity & \\
\hline kilometer per second $(\mathrm{km} / \mathrm{s})$ & 0.6214 & miles per second $(\mathrm{mi} / \mathrm{s})$ \\
kilometer per second $(\mathrm{km} / \mathrm{s})$ & 3280.84 & feet per second $(\mathrm{ft} / \mathrm{s})$ \\
\hline
\end{tabular}

\section{Abbreviations}

ASST Average soil and sedimentary deposit thickness

CEUS Central and eastern United States

GMNA Geologic map of North America

NCM National Crustal Model

SEVR Sedimentary and extrusive volcanic rocks

SGMC State Geologic Map Compilation

USGS U.S. Geological Survey

WUS Western United States 


\title{
3D Geologic Framework for Use with the U.S. Geological Survey National Crustal Model, Phase 1-Western United States
}

\author{
By Oliver S. Boyd
}

\begin{abstract}
A 3D geologic framework is presented here as part of the U.S. Geological Survey National Crustal Model for the western United States, which will be used to improve seismic hazard assessment. The framework is based on 1:250,000 to 1:1,000,000-scale state geologic maps and depths of multiple subsurface unit boundaries. The geology at or near the Earth's surface is based on published maps with modifications to remove discontinuities across state borders. Extrapolation of rock type and age in the subsurface is achieved by iterative stripping of units of a given age, nearest neighbor interpolation of the remaining units, and constraints on basement geology. The subsurface depth of the interfaces between units is determined by a range of models with varying quantity and quality of constraints. Bedrock depth is derived primarily from a proxy model with added geophysical constraint in some areas. The depths to the base of Cenozoic and Phanerozoic sedimentary and extrusive volcanic rocks are constrained by geophysical methods in many areas. Elsewhere, a simple method is used to estimate their subsurface depth based on the distance to the edge of the geologic units. The remaining continental units are evenly distributed above, below, and between depending on age. The oceanic crust is treated as a simple four-layer model with the added complexity of subduction beneath the North American plate along the Cascadia subduction zone.

Refinements to this technique may be accomplished in future versions of the model with more specific information including the location of faults to produce discontinuities in geologic structure and additional information obtained from boreholes and geophysical studies. Further improvements to the geologic framework may be made by incorporating information from more local studies, for example, hydrogeologic studies.
\end{abstract}

\section{Introduction}

Appreciable seismic hazard and risk are nearly ubiquitous across the United States (U.S.) as evidenced by large historic earthquakes along the San Andreas Fault, within the New Madrid seismic zone, and near Washington D.C. and seismically vulnerable structures built before modern building codes in the central and eastern U.S. A major factor in assessing seismic hazard is the ground motion produced by an earthquake, which is strongly influenced by the subsurface geology. For example, because of differences in mechanical properties, ground composed of poorly consolidated sediments typically undergoes greater intensity shaking than ground composed of bedrock such as granite or sandstone. Ground shaking within sedimentary basins may be of greater duration and amplitude relative to locations outside of these basins because of mechanical properties and wave focusing. Knowledge of the surface and subsurface geologic variations can be used to constrain, interpolate, and extrapolate geophysical data and estimate the three-dimensional (3D) geophysical structure across the U.S.

A U.S. Geological Survey (USGS) National Crustal Model (NCM) will assist with earthquake hazard estimates in the USGS National Seismic Hazard Model by supporting estimates of ground shaking in response to an earthquake. Improved hazard assessments may also be used for planning and risk assessments but are not intended for site-specific engineering applications. The NCM is composed of geophysical attribute-depth profiles on a 1-kilometer $(\mathrm{km})$ grid from which can be extracted metrics needed for ground motion models (GMMs). Quantities of immediate interest are the time-averaged shear-wave velocity in the upper 30 meters $(\mathrm{m})$ and the depths to 1.0 and $2.5 \mathrm{kilometers} / \mathrm{second}(\mathrm{km} / \mathrm{s})$ shear-wave velocity. The NCM has the flexibility to provide additional metrics such as fundamental frequency, a fully frequency-dependent site response function derived from 1D, 2D, or 3D analyses, or 3D geophysical volumes for wavefield simulations. The NCM may also benefit other aspects of seismic hazard analysis including better accounting for path-dependent attenuation and geometric spreading and more accurate estimation of earthquake source properties such as hypocentral location, magnitude, focal mechanism, and stress drop.

Each geophysical profile within the NCM is based on subsurface geology, pressure, and temperature coupled with mineral and rock physics theory and porosity and attenuation models. The primary elements used to construct the NCM are: (1) depth 
to bedrock and basement (Shah and Boyd, 2018); (2) 3D geologic framework (this report); (3) petrologic and mineral physics database (Sowers and Boyd, 2019); (4) 3D temperature model; (5) calibration of a porosity and attenuation model; and (6) validation. These elements make use of a host of geology, borehole, gravity, and seismic datasets to connect subsurface geological variability with geophysical attributes and seismic response.

Construction of the 3D geologic framework for the NCM requires information about the surface and subsurface geology that is continuous across state borders and fully spans the study area. The 3D geologic framework uses published maps of nearsurface and basement geology and multiple primary subsurface layer boundaries including the depth to: (1) bedrock, (2) base of Cenozoic and Phanerozoic sedimentary and extrusive volcanic rocks (SEVR), (3) middle crust, and (4) Moho (Mohorovičić discontinuity). Phase 1 of model construction, the main subject of this report, covers the western United States (WUS) west of $100^{\circ} \mathrm{W}$ longitude. Phase 2 covers the central and eastern United States (CEUS) east of this longitude. Datasets for Phase 2 collected to date are shown here to illustrate progress made and potential problems. A data release accompanies this report (Boyd, 2019), which consists of geologic profiles on a regular grid across the western U.S.: https://doi.org/10.5066/P9SBQENM. Codes to produce geologic profiles are available at https://code.usgs.gov/ghsc/nshmp/ncm/GeoFram.

\section{Geology and Age of Rocks at or Near the Earth's Surface}

Geologic maps showing dominant lithology and age at or near the Earth's surface are derived from the USGS State Geologic Map Compilation (SGMC; Horton, 2017; Horton and others, 2017) and the Geologic Map of North America (GMNA; Garrity and Soller, 2009). SGMC maps in the WUS have map scales ranging from 1:250,000 to 1:1,000,000, and the GMNA has a map scale of 1:5,000,000. The maps are distilled into a common set of 164 ages, spanning from the Holocene to Archean (table 1.1), and 209 lithologic types (table 2.1) composed of unconsolidated material and sedimentary, volcanic, metamorphic, and igneous rock types (see appendix 1 and 2 for age and lithologic data dictionaries).

The SGMC database is available as an esri geodatabase, shapefile, or tables of comma separated values; the shapefile is used here (Horton, 2017). Each polygon within the shapefile consists of multiple attributes including minimum and maximum age and up to three major and five minor rock types; in many cases, only one major rock type is specified, and the other entries are empty. The ages are derived from the FULL_MIN and FULL_MAX age fields in the age table, which are built from the definitions in the age table data dictionary with designations as fine as age based on the 2016 International Chronostratigraphic Chart (International Commission on Stratigraphy, 2016). There are several age entries in the shapefile that are not present in the data dictionary - these are mapped to data dictionary values (appendix 1). The rock type data dictionary used here (appendix 2) is derived from an earlier version of the State geologic map compilation consisting of 209 lithologic units.

The GMNA database is available as a shapefile. Each polygon within this shapefile also has a minimum and maximum age but only one rock type. GMNA ages are mapped into the SGMC data dictionary (appendix 1), and GMNA rock types are mapped into the rock type data dictionary used here (appendix 2).

Generally, analysis is performed on the minimum age field because it is assumed to represent the top of the geologic unit, though in most instances the choice is inconsequential because the minimum and maximum age field are the same. In some cases, however, the difference between these fields is significant. For example, granodiorite units in parts of the Sierra Nevada have a minimum age of Tertiary and maximum age of Lopingian, but the description is Mesozoic. For intrusive units with a large span in age, the description field is interrogated for a general unit age, which is then used for further analysis. In a few cases (0.04 percent of map area), igneous and metamorphic units have unknown age. In these cases, the age of the nearest unit with a similar rock type, either intrusive igneous or metamorphic, is assigned.

There are two cases in the SGMC shapefiles where minimum ages have labels that are older than maximum ages. In Virginia, some granites are assigned a minimum age of Mississippian and maximum age of Pennsylvanian ( 0.0004 percent of the NCM map area). In Oregon, some argillites are assigned a minimum age of Carnian and maximum age of Norian (0.004 percent of the NCM map area). These errors are corrected by simply switching the age labels.

Values within the shapefile polygons are rasterized onto a 1-km grid and several modifications are made in order to follow certain assumptions and to make the maps continuous across state and country borders. Units having a minimum age older than Miocene are assumed to be lithified, following studies that define units older than Miocene as the top of bedrock (for example, Gutentag and others, 1984; Pelletier and others, 2016). If the first major rock type is older than Miocene but is listed as an unconsolidated lithology, the other two major rock types are checked and the first that is lithified is chosen. If there are no other types or they are not lithified, the rock type that represents a lithification of the unconsolidated sediment is chosen. For example, silt becomes siltstone, sand becomes sandstone, and so forth.

Geologic discontinuities across state and country borders are removed by comparing age and lithology across the border and making algorithmic decisions to resolve the discrepancy. In many cases, unit contacts are continuous across state and country borders, but the lithology and age assigned to the unit are not. In many such cases, differences are generally subtle where on 
one side a slightly different lithology is chosen, or a more specific age is assigned. When contacts are not continuous, this usually results from differences in resolution where a mapped unit is subdivided by one state geologist and is not by the other.

Modifications to the geologic maps are typically made to the unit on the side of the border that has a smaller mapped area, which minimizes changes that are made to the geologic maps and has the effect of reducing the resolution in that area when differences in resolution across a border are present. Basic exceptions to this rule were made after visual inspection of the maps in order to maximize continuity (see appendix 3 ).

A few of the original map units, about 0.04 percent of the NCM project area, have no age assigned. Most of these are from the GMNA in western Canada and to a lesser extent in western Mexico. In these cases, the age of the nearest similar lithology is used. Additionally, generic rock types such as sedimentary, igneous, volcanic, and metamorphic, are replaced with more specific lithologies of the same type by comparison with nearby units having the same age. The resulting National-scale geologic age and lithology maps are shown in figures 1 and 2, of which the western parts are used for the Phase 1 analysis.

\section{Lithology and Age of Subsurface Layers}

\section{Oceanic Crust}

Oceanic crust is generalized as being composed of at least four lithologic layers: unconsolidated sediment, basalt, gabbro, and peridotite (see fig. 7.4 in Brown and Mussett, 1981). Sedimentary rock units may also overlay the basalt layer. The age of the crust is taken from Müller and others (2008) and is needed to assess the geotherm in the oceanic crust.

\section{Continental Crust}

The NCM subsurface continental geology is essentially an extrapolation of geology at the Earth's surface, whereby depositional and extrusive volcanic units, ordered by age, are iteratively stripped, and the distribution of remaining units, which are either older or intrusive, is interpolated. The extrapolation of intrusive and Proterozoic and Archean units, however, is limited by the basement geology map constructed by Whitmeyer and Karlstrom (2007). Initially, only the vertical ordering of layer age and lithology is determined, without regard to the depth of each unit. At a later stage, with bedrock and basement layer depths in hand, depths are assigned, and the 3D geologic framework model is completed (see section "Layer Elevation").

More specifically, the initial subsurface age and lithologic layer models are constructed using use an iterative nearestneighbor interpolation. Non-intrusive geologic units (for example, Holocene alluvium), ordered by median age, are iteratively stripped. The first units to be stripped are Holocene deposits having a median age of 6 thousand years (ka) and the last, Paleoarchean, having a median age of 3.4 billion years. After units of a given age are stripped, nearest-neighbor interpolation is used to estimate the distribution of the remaining geologic units; remaining units grow uniformly in all directions to fill in the gaps. This produces a crystal-like patchwork of remaining units, which is obviously unnatural, but is a reasonable choice given no other constraints on the subsurface distribution of geologic units.

Age within the lower crust and lithospheric mantle is assumed to be that of the overlying material but the lithology is assumed to be pyroxenite in the lower crust and peridotite in the mantle (Wilshire, 1990).

This approach can be improved upon with better resolved ages of materials at the Earth's surface and greater a priori knowledge of subsurface geology, as can be obtained from drill holes and geophysical studies including seismic reflection and refraction, gravity, and aeromagnetics. For example, one limitation of the method used in this report is that two lithologies with the same mapped age that meet in the subsurface will meet along a vertical boundary and not overlap. It may be that one unit is older than the other and should lie below. Or, the two units were in fact deposited at the same time and the boundaries interfinger, producing a series of prograde and retrograde depositional sequences. Note also that because of the nearest-neighbor interpolation, the boundary will be equidistant from the outcrops of the respective units, which is unlikely to be the actual case.

All age distinctions from the geologic maps are retained to be able to properly order geologic units in the subsurface. All rock distinctions are also retained to be able to fully account for potential geophysical variability in the subsurface, which includes variability due to mineral physical properties (Sowers and Boyd, 2019) as well as variability that will be actualized after calibration of porosity and attenuation models. 


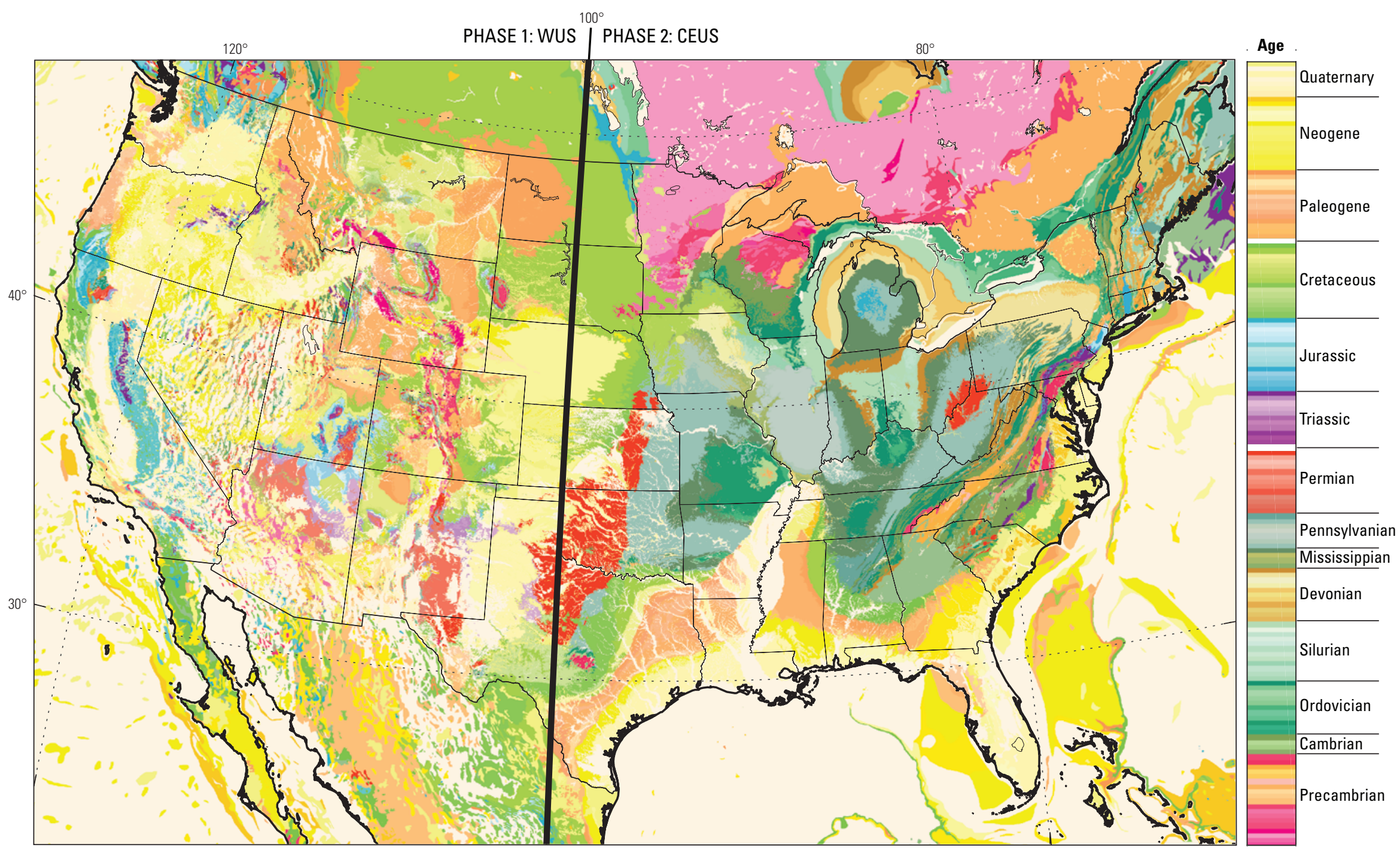

Figure 1. Merged geologic map of the United States and southern Canada and northern Mexico, showing, in most cases, the minimum age, as derived from the minimum age fields in the Geologic Map of North America database (Garrity and Soller, 2009) and the State Geologic Map Compilation (SGMC; Horton and others, 2017; Horton, 2017). For intrusive units with a large span in age, the description field in the SGMC is used for a general unit age. In a few cases, igneous and metamorphic units have unknown age. In these cases, the minimum age field of the nearest unit with a similar rock type, either intrusive igneous or metamorphic, is assigned. Note that state maps compiled in the SGMC for several states around the Great Lakes show only bedrock geology, such that young glacial deposits are underrepresented on this map. Colors are taken from the Red-Green-Blue color code according to the Commission for the Geologic Map of the World (https://www.ccgm.org). WUS, western United States; CEUS, central and eastern United States. 


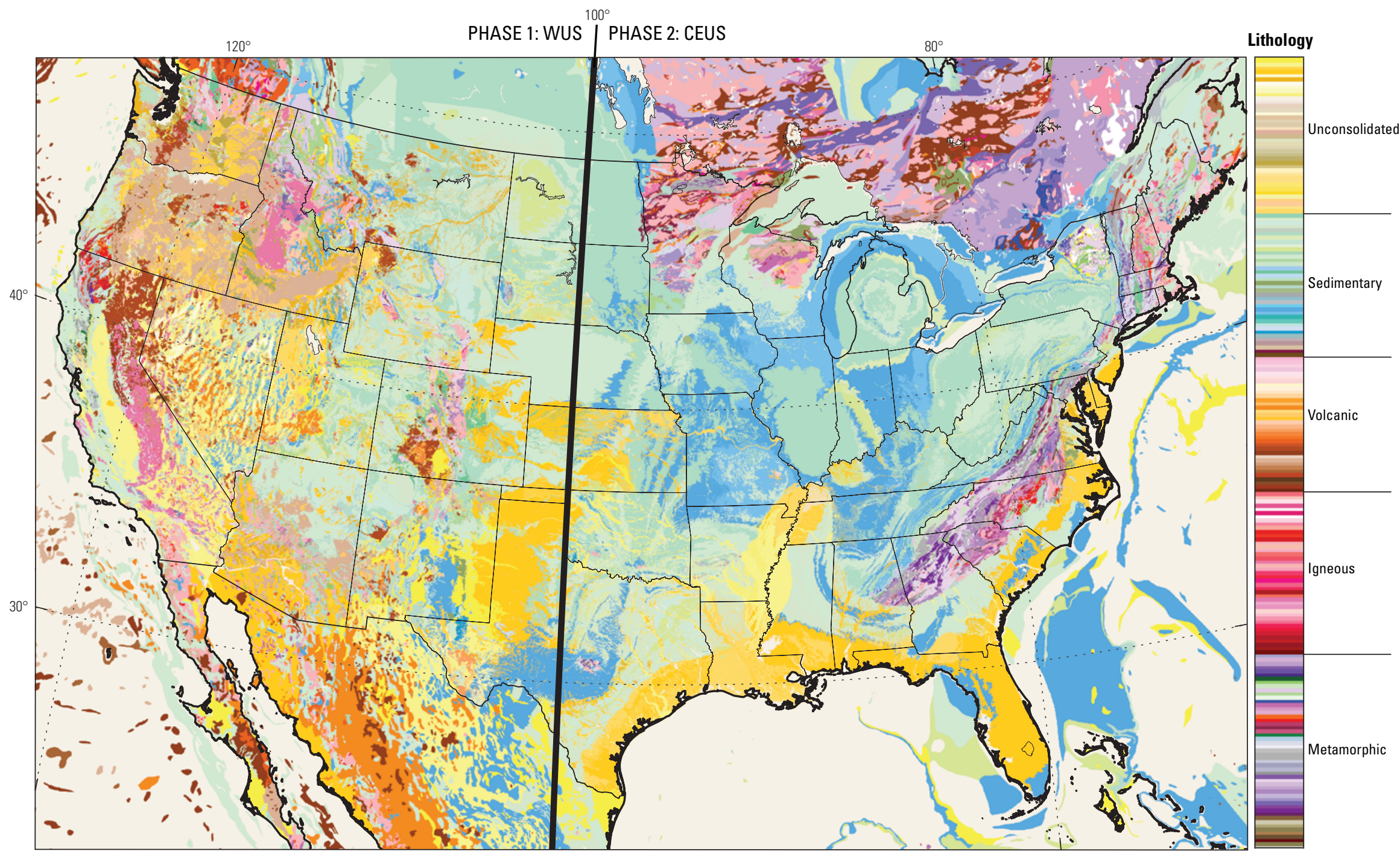

Figure 2. Dominant mapped lithology of the United States and southern Canada and northern Mexico. Note that state maps compiled by the State Geologic Map Compilation (Horton and others, 2017; Horton, 2017) for several states around the Great Lakes show only bedrock geology, such that young glacial deposits are underrepresented on this map. Lithologic colors are adapted from Moyer and others (2005) (and can also be found at https://mrdata.usgs.gov/catalog/lithrgb.txt, last accessed Oct. 2018. WUS, western United States; CEUS, central and eastern United States. 


\section{Subsurface Layer Depth and Elevation}

\section{Oceanic Crust}

For much of the oceanic crust, the basalt layer is assumed to lie directly below the unconsolidated sediment layer whose top is defined by the gridded General Bathymetric Chart of the Oceans (Weatherall and others, 2015; GEBCO, 2018), a global 30 arc-second elevation model. The thickness of the unconsolidated sediment layer in the oceans is defined by Whittaker and others (2013). In Cascadia, where the Juan de Fuca slab subducts beneath the North American plate, the top of the basalt layer is defined by Slab2 (Hayes and others, 2018). The basalt layer is assumed to be $2 \mathrm{~km}$ thick, the gabbro beneath, $5 \mathrm{~km}$ (see fig. 7.4 in Brown and Mussett, 1981), and the peridotite layer extends to the base of the model.

\section{Continental Crust}

\section{Layer Depth}

Within the continental extent of the NCM, bedrock and basement depth surfaces of a given age or lithologic distinction serve to pin the depths of those layers within the 3D geologic framework. Depositional layers of intermediate age are evenly distributed between younger and older units, whereas intrusive, Proterozoic, and Archean units extend down to the base of the upper crust. Algorithmic details of the process of assigning layer depths are discussed in subsequent sections.

Following Shah and Boyd (2018), who compiled data from multiple sources to produce maps of the depth to bedrock and basement in the WUS, bedrock is defined as the depth to the base of unconsolidated sediment, that in many cases, is assumed to be the depth to pre-Miocene strata (see for example, Pelletier and others, 2016). In the study of Shah and Boyd (2018), basement, however, has two definitions. In much of the WUS, it is defined as the depth to pre-Cenozoic strata (see for example, Saltus and Jachens, 1995); in eastern parts of the WUS and much of the CEUS, it is the depth to Proterozoic and Archean rocks (see for example, Marshak and others, 2017). In this report, basement is referred to as either the base of Cenozoic or Phanerozoic SEVR.

Because of the change in definition of basement in Shah and Boyd (2018), their basement surface is discontinuous and not defined in all areas of the WUS. In this report, minor improvements are made to the work of Shah and Boyd (2018), and the bedrock and basement surfaces are extended over the full extent of NCM continental crust west of -100 degrees longitude. Preliminary results for Phase 2 in the CEUS appear in the following figures but are not detailed in this report and are subject to change.

\section{Depth to Top of Bedrock Layer}

The depth to the top of bedrock is constructed from multiple studies (table 1; fig. 3), which make use of topographic, gravity, and (or) well data. The primary WUS depth to bedrock surface is from Shah and Boyd (2018). Other datasets that supplement this surface include the thickness of Quaternary sediments from the San Francisco Bay Area geologic model (Aagaard and others, 2010), the depth to bedrock layer from Branscombe and others (2017) in Canada's Alberta Province, and the average soil and sedimentary deposit thickness (ASST) model of Pelletier and others (2016) in Mexico, most of Canada, and much of the CEUS, which is the same background model used in Shah and Boyd (2018). In the oceans, the thickness of unconsolidated sediments is constrained to be zero where hard rock crops out.

\section{Depth to Top of Basement Layers}

The differences in definition of the depth to basement between the WUS and CEUS would cause unrealistic discontinuities in subsurface geology if simply stitched together. Regrettably, neither the depth to the base of Cenozoic SEVR nor the depth to the base of Phanerozoic SEVR has been mapped at all locations across the WUS. Continuous extensions of each of these representations of depth to basement across the western U.S. are thus needed to estimate geophysical parameters that vary continuously within geologic layers. To achieve this goal, an algorithm was developed to assign relative thickness of subsurface geologic units based on the closest distance to the edge of each unit, which is found during each iteration of stripping as described in the prior section "Lithology and Age of Subsurface Layers." These distances are used for two purposes: (1) to distribute layers above bedrock, between the top of bedrock and the base of Cenozoic SEVR, and between the base of Cenozoic SEVR and the base of Phanerozoic SEVR; and (2) to determine the depth to the base of Cenozoic and Phanerozoic SEVR where they are undefined in Shah and Boyd (2018).

For the depth to the base of Cenozoic SEVR in regions where it was not determined in Shah and Boyd (2018) - the hashed regions in Oregon, Washington, Idaho, California, the Colorado Plateau, the CEUS, Mexico, and Canada outlined by the heavy 
Table 1. Datasets used to produce bedrock and depth to the base of Cenozoic and Phanerozoic sedimentary and extrusive volcanic rocks (SEVR) surfaces in western North America.

[Km, kilometer; WUS, western United States; CEUS, central and eastern United States; NCM National Crustal Model]

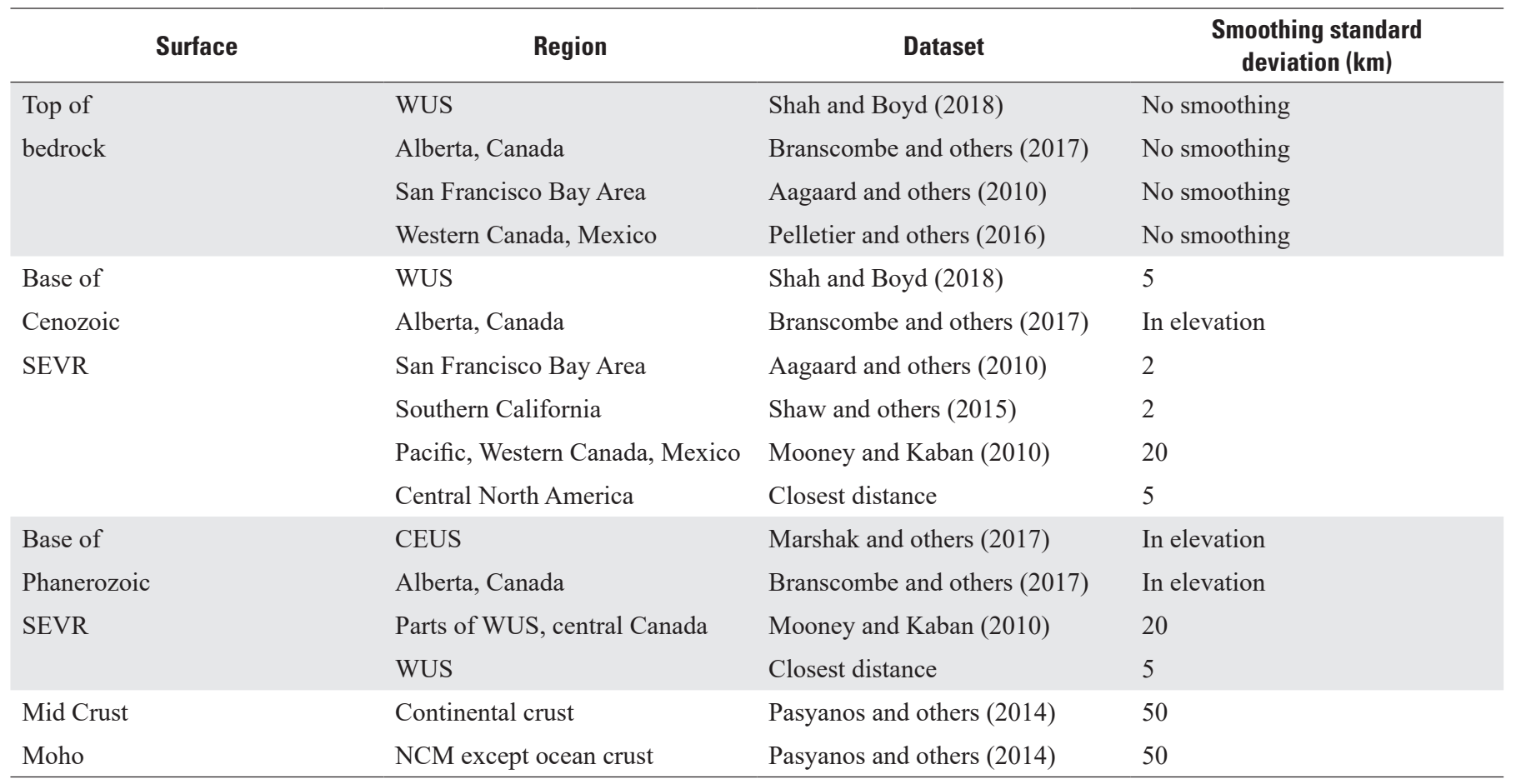

dashed line in figure 4 - the sum of the closest distances to the edge of non-intrusive Cenozoic units is smoothed and the square root of this value is scaled. The smoothing function is Gaussian with a variable standard deviation equal to two-thirds of the closest distance at each location thereby maintaining the location of the unit edge and smoothing out the artefacts produced by the algorithm. This method is straightforward, yielding zero depth where intrusive and Mesozoic and older rocks crop out at the surface and greatest depth at the greatest distance from the edge of Cenozoic deposits. The square root is an arbitrary choice that produces a relatively realistic pattern of deposition of Cenozoic strata. A smoothly varying map of scaling factors is constructed to produce a maximum depth of about $10 \mathrm{~km}$ in Oregon and Washington as observed for the thickness of Cenozoic strata in this region (Saltus, 1993), Cenozoic thicknesses that are similar to values from Shah and Boyd (2018) in the Basin and Range, and Cenozoic thicknesses that are similar to those observed for basins along the Front Range of the Rocky Mountains.

The depth to the base of Cenozoic SEVR is further modified by including multiple models both within and outside the WUS. In the WUS, additional models include the base of Cenozoic SEVR from the San Francisco Bay Area (Aagaard and others, 2010) and southern California (Shaw and others, 2015) geologic models. In Canada's Alberta Province, the depth to Cretaceous sedimentary rock from Branscombe and others (2017) is used. And in parts of the Pacific and Mexico, what is assumed to be the base of Cenozoic SEVR from Mooney and Kaban (2010) is used. This assumption is based on the studies used to produce that model in the WUS, for example, Jachens and Moring (1990) in the Basin and Range. In Mooney and Kaban (2010), however, much of the model is based on Frezon and others (1983), which is not documented well enough to determine the age of the rock above basement but appears to be depth to Proterozoic and Archean between the Appalachians and Rockies and depth to Mesozoic elsewhere.

The depth to the base of Phanerozoic SEVR where it was not determined by Shah and Boyd (2018), which is indicated by the hashed region outside of the heavy dashed line in the CEUS in figure 5, is resolved through a method similar to that used for the depth to the base of Cenozoic SEVR by smoothing the sum of closest distances to the edge of non-intrusive Phanerozoic units, and scaling the square root of this sum. The scaling values are the same as those used for the Cenozoic SEVR surface with the exception that in the far WUS in Washington, Oregon, western Nevada, and California where the distances are controlled by igneous outcrops rather than older Proterozoic rock, the Phanerozoic scaling values are a factor of 8 greater than the Cenozoic to account for the increase in time over which deposition could occur. Note, however, that where this method has been applied, particularly in the WUS, an exceptional amount of tectonism since the Proterozoic continues to this day (Dickinson, 2004). This surface is undoubtedly far more varied than depicted here, and its depth is highly uncertain. 


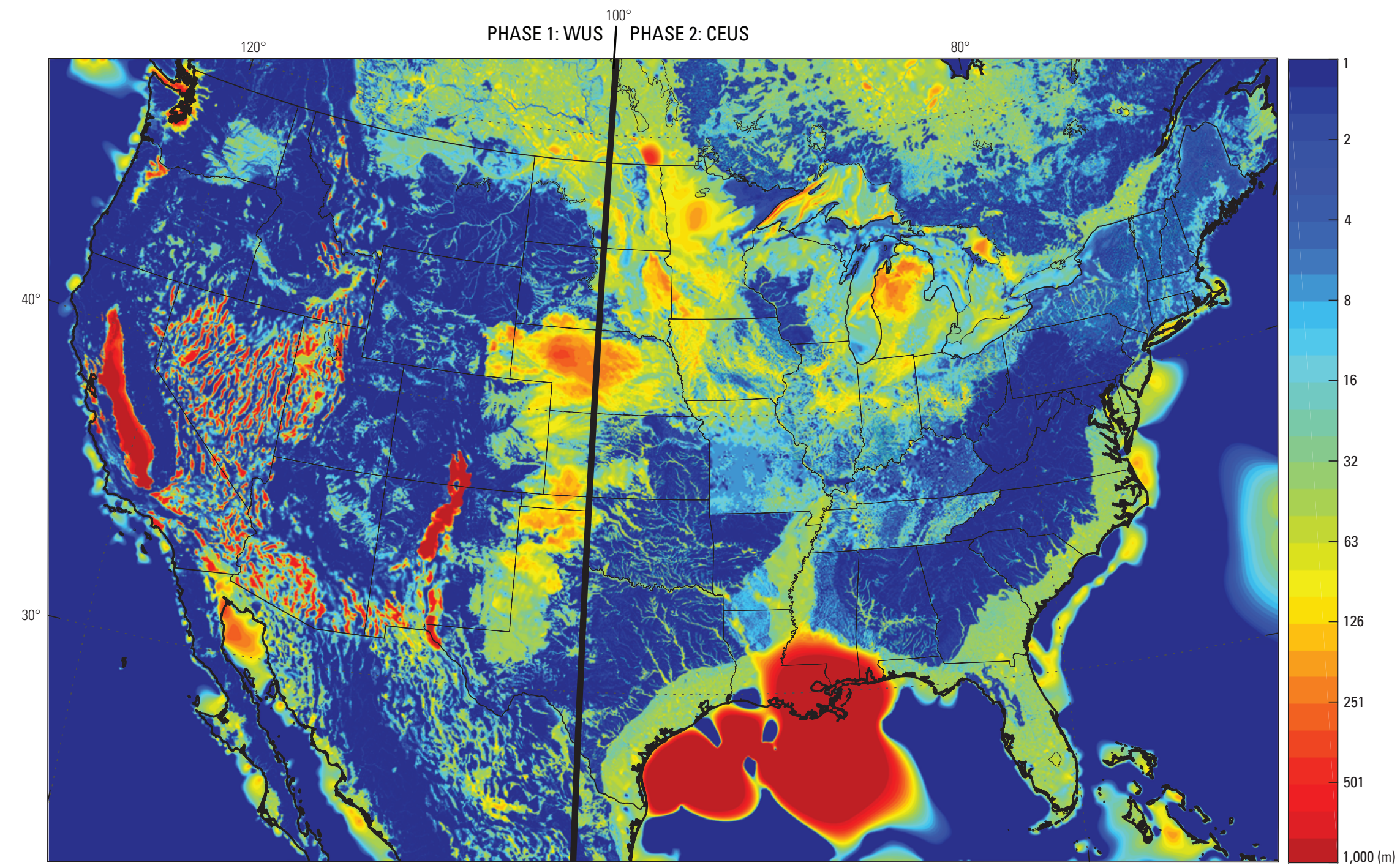

Figure 3. Map of depth to bedrock. The region of the United States in Phase 1 is from Shah and Boyd (2018) with several modifications including additional datasets offshore and in Canada, Mexico, and the San Francisco Bay Area. Bedrock depths in the Phase 2 region are still under development and subject to change. WUS; western United States; CEUS, central and eastern United States; m, meters. 


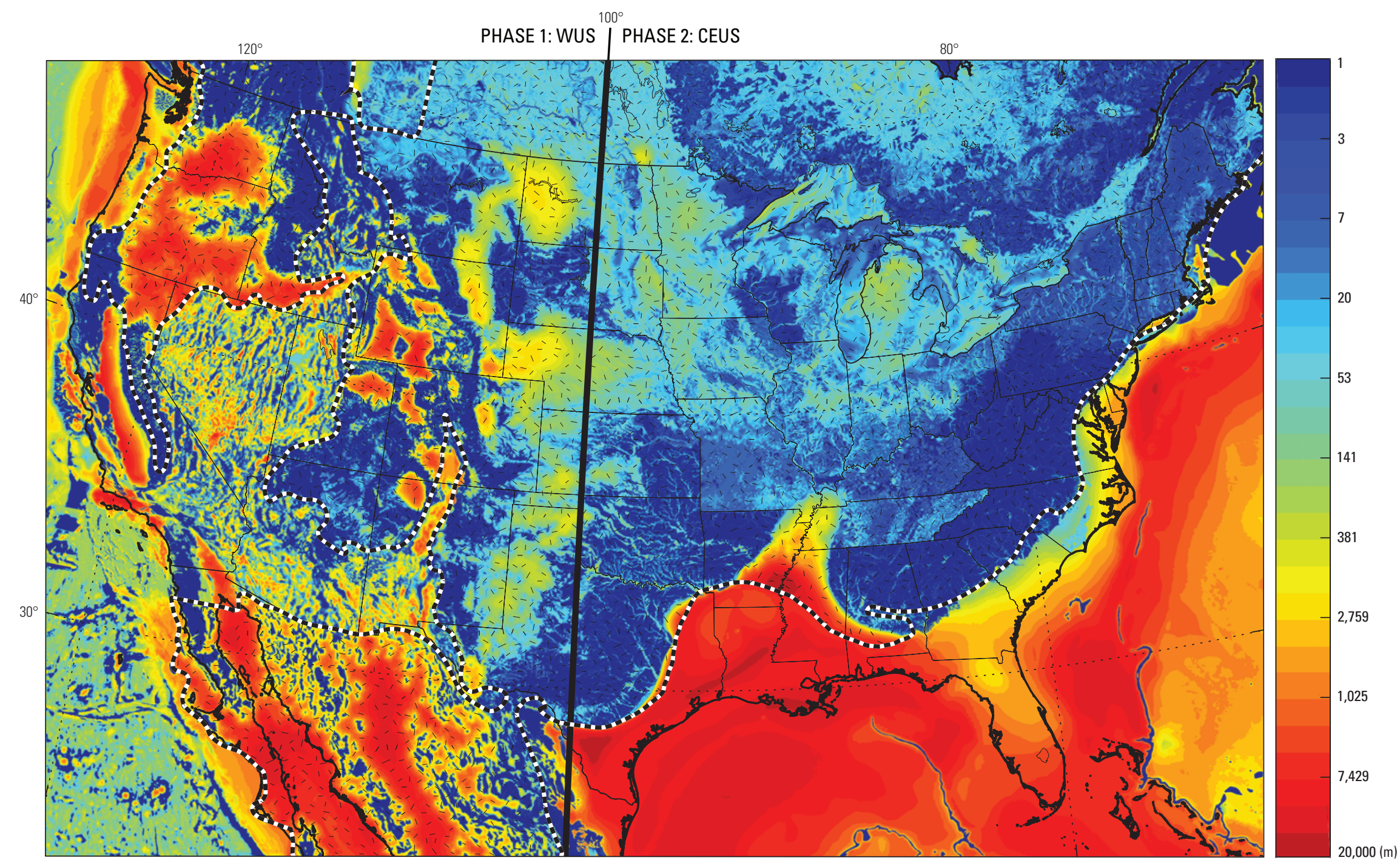

Figure 4. Map of thickness of Cenozoic sedimentary and extrusive volcanic rocks (SEVR). The hashed region demarcates the areas in Oregon,

Washington, Idaho, northern California, the Colorado Plateau, and central North America where the closet distance to intrusive or Mesozoic and older outcrop method was used to derive Cenozoic SEVR thickness. Outside of this line, the Shah and Boyd (2018) model was modified with thickness of

Cenozoic SEVR maps in Canada, Mexico, the San Francisco Bay Area, and southern California. Depth to the base of Cenozoic SEVR in the Phase 2 region is still under development and subject to change. WUS; western United States; CEUS, central and eastern United States; m, meters. 


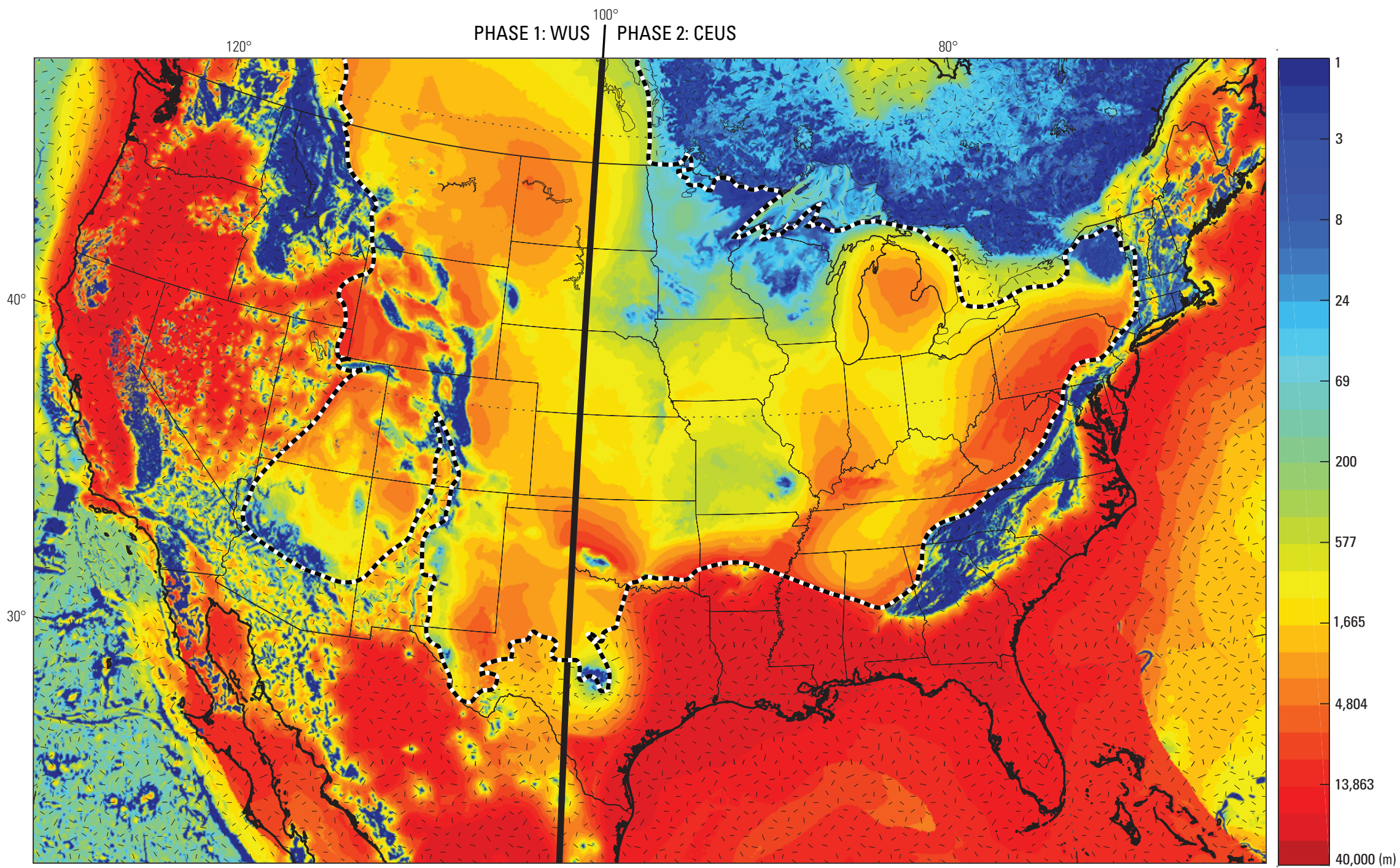

Figure 5. Map of thickness of Phanerozoic sedimentary and extrusive volcanic rocks (SEVR). Dashed line demarcates the hashed area outside of central North America where the closet distance to intrusive or Proterozoic and Archean outcrop method was used to derive the base of Phanerozoic SEVR. Within this line, the Shah and Boyd (2018) model was modified with thickness of Phanerozoic SEVR maps in parts of the U.S. and Canada. Depth to the base of Phanerozoic SEVR in the Phase 2 region is still under development and subject to change. WUS; western United States; CEUS, central and eastern United States; $\mathrm{m}$, meters. 
Like the depth to the bottom of Cenozoic SEVR, additional datasets are combined with the work of Shah and Boyd (2018), which is based on Marshak and others (2017). These additional datasets include the depth to Proterozoic and Archean basement from Alberta's 3D Provincial Geologic Framework Model (Branscombe and others, 2017), and the depth to, presumably, Proterozoic and Archean basement from Mooney and Kaban (2010) in central Canada and in a small area adjacent to Marshak and others (2017) in eastern Idaho and northern Utah.

\section{Depth to Top of Lower Crust and Moho}

The depth to mid-crustal layer boundaries and the Moho are estimated on a 1-degree global grid by Pasyanos and others (2014) using surface wave dispersion in the frequency band 5-40 millihertz $(\mathrm{mHz})$. The mid-crustal boundaries are simplified by averaging the boundaries between upper and middle crust and middle and lower crust so that there is a single boundary between upper and lower crust. The depth to the Moho is further refined using the conterminous U.S. Moho depth map of Buehler and Shearer (2017), which combines Pn arrival times, the seismic P-wave phase that travels along the Moho, at USArray stations and the crustal velocities of Shen and Ritzwoller (2016).

\section{Layer Elevation}

Geologic profile layer contacts in the NCM are specified in elevation. Therefore, datasets that are provided as depth to the layer boundary are converted to elevation. The Alberta surfaces (Branscombe and others, 2017) and Proterozoic/Archean surface (Marshak and others, 2017) are provided in elevation. All others are provided as depth. Conversion to elevation is achieved by subtracting these layer depths from smoothed versions of the GEBCO elevation model. The smoothing kernel is Gaussian with variable standard deviation chosen to approximately match the spatial frequency content, or roughness, of the original surface (table 1). The smoothing is only applied to the base of Cenozoic and Phanerozoic SEVR surfaces to prevent young geomorphic features from being mapped onto older subsurface contacts.

Datasets composing a given surface (for example, thickness of Cenozoic SEVR) are combined in such a way as to minimize discontinuities moving from one to the other. If necessary, each surface from a given source is extrapolated over the entire study area using nearest neighbors. A weight is assigned to this surface equal to 1 where it is used and 0 elsewhere. This binary weight map is then smoothed with a Gaussian kernel having a standard deviation of $10 \mathrm{~km}$. The surfaces are then combined in a weighted average. For example, the base of Phanerozoic SEVR surface elevation is equal to

$$
\left(w_{M K e M K}+w_{M} e_{M}+w_{B} e_{B}+w_{C D} e_{C D}\right) /\left(w_{M K}+w_{M}+w_{B}+w_{C D}\right)
$$

where

$$
\begin{aligned}
w & \text { is weight, } \\
e & \text { is elevation, }
\end{aligned}
$$

and the subscripts MK, M, B, and CD refer to Mooney and Kaban (2010), Marshak and others (2017),

Branscombe and others (2017), and closest distances, respectively.

Because the weights quickly go to zero outside of the region in which a particular model is kept, the final map is not strongly sensitive to how the constituent maps are extrapolated.

During construction of the geologic profiles, it may be the case that units are 'missing,' as alluded to earlier, where a bedrock unit is present at the surface but depth to bedrock is greater than zero. In such cases, Holocene residuum is inserted between the surface and bedrock. Similarly, there are instances when the bedrock and base of Cenozoic SEVR surfaces do not coincide but there are no Cenozoic rock units identified from extrapolating units at the Earth's surface. In such cases, Tertiary sedimentary rock is inserted. If Mesozoic or Paleozoic layers are 'missing,' Mesozoic metasedimentary rock is inserted. After the initial geologic framework is constructed, these inserted units are compared to the surrounding material. If a geologic unit in the layer of interest in a neighboring profile has been assigned (not by insertion), the value from the neighboring profile is used for the inserted unit. This procedure resolves 96 percent of the inserted units, leaving 0.4 percent of the 117 million units in the $3 \mathrm{D}$ geologic framework inserted. 


\section{Model Cross Sections}

Four east-west cross section locations are shown in figure 6. In figure 7, the modeled age is shown, and in figure 8 the lithology is shown as examples of the geometry and level of complexity of the 3D framework. From north to south, the cross

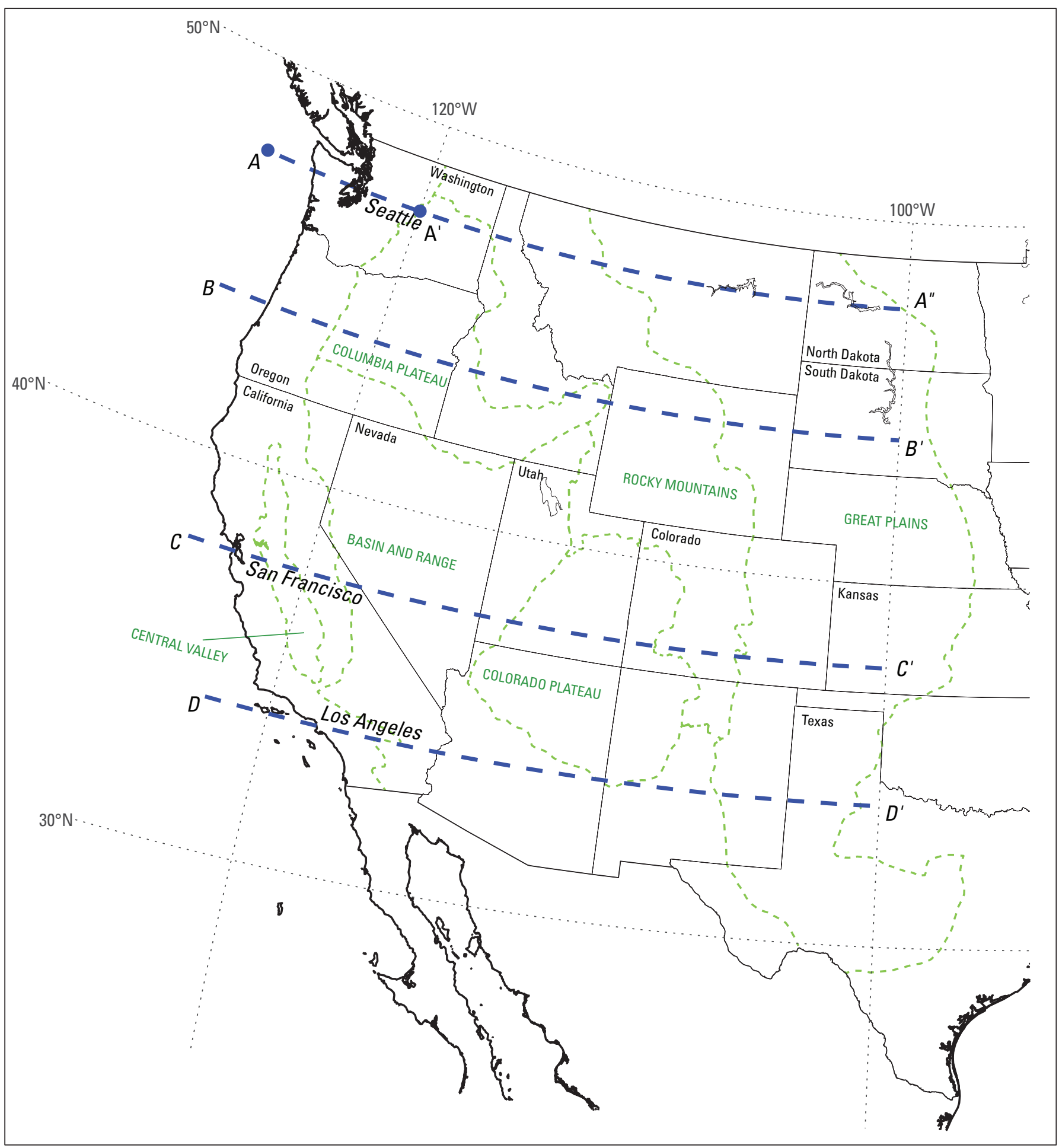

Figure 6. Cross-section profile locations in the United States. Physiographic provinces outlined using green dashed lines are adapted from Fenneman and Johnson (1946). Blue dashed lines indicate the profile locations, from north to south, seen in figures 7 and 8 . The cross sections in figure 9 lie along the northernmost profile between $A$ and $A$ '. 
WEST

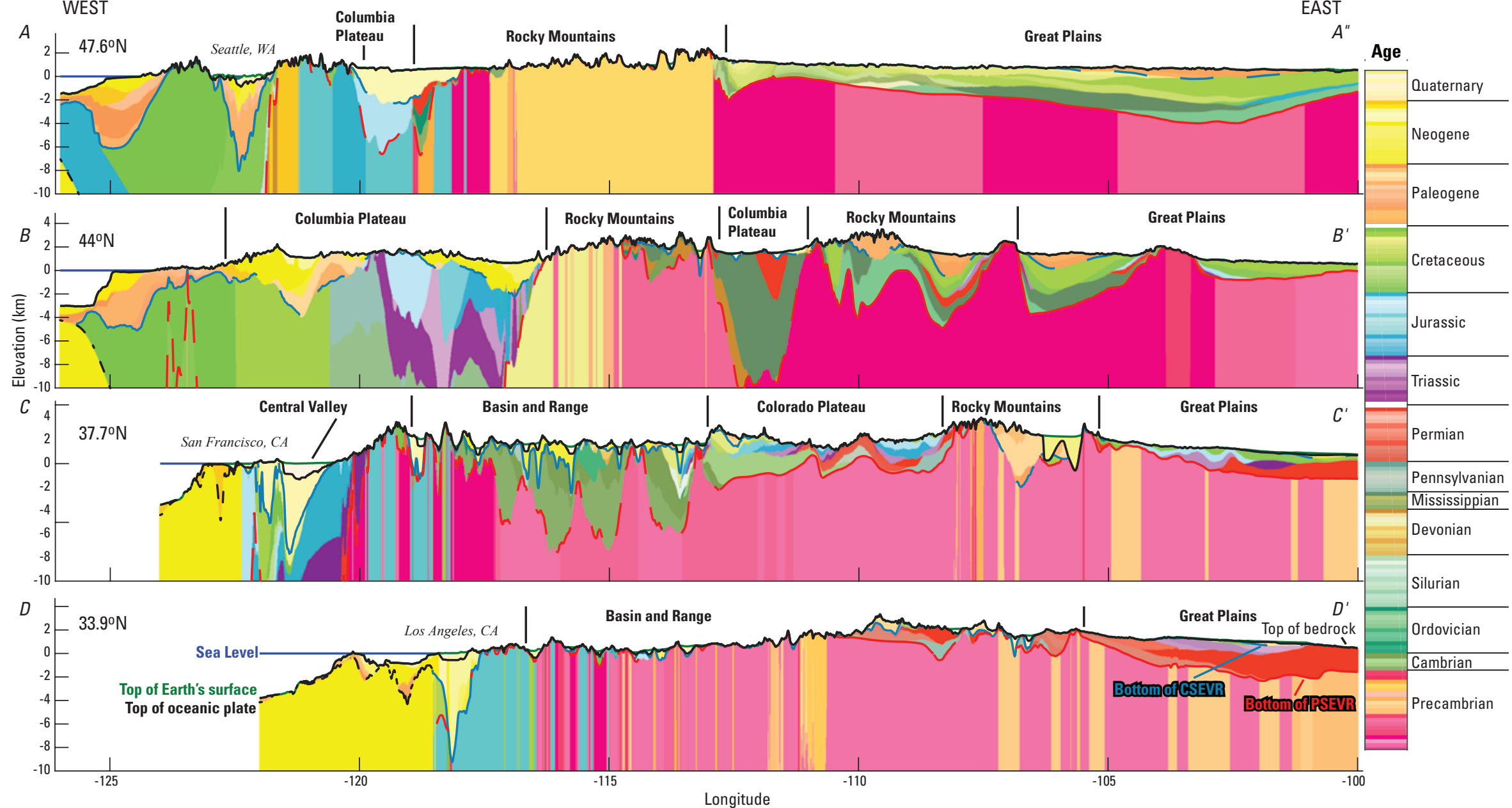

Figure 7. Cross-sections of subsurface age in the United States. Profile locations, from north to south, are shown in figure 6. The green line is the top of the Earth's surface, the blue line is sea level, the black line is the top of bedrock, the solid or dashed navy-blue line is the bottom of Cenozoic sedimentary and extrusive volcanic rocks (CSEVR), the solid or dashed red line is the bottom of Phanerozoic sedimentary and extrusive volcanic rocks (PSEVR), and the orange line is the top of the oceanic plate. Dashed lines indicate depths determined from the closest distance to the edge of either Cenozoic or Phanerozoic non-intrusive units. Younger rocks lying beneath older rocks are igneous intrusions. Vertical exaggeration approximately 20 times. 

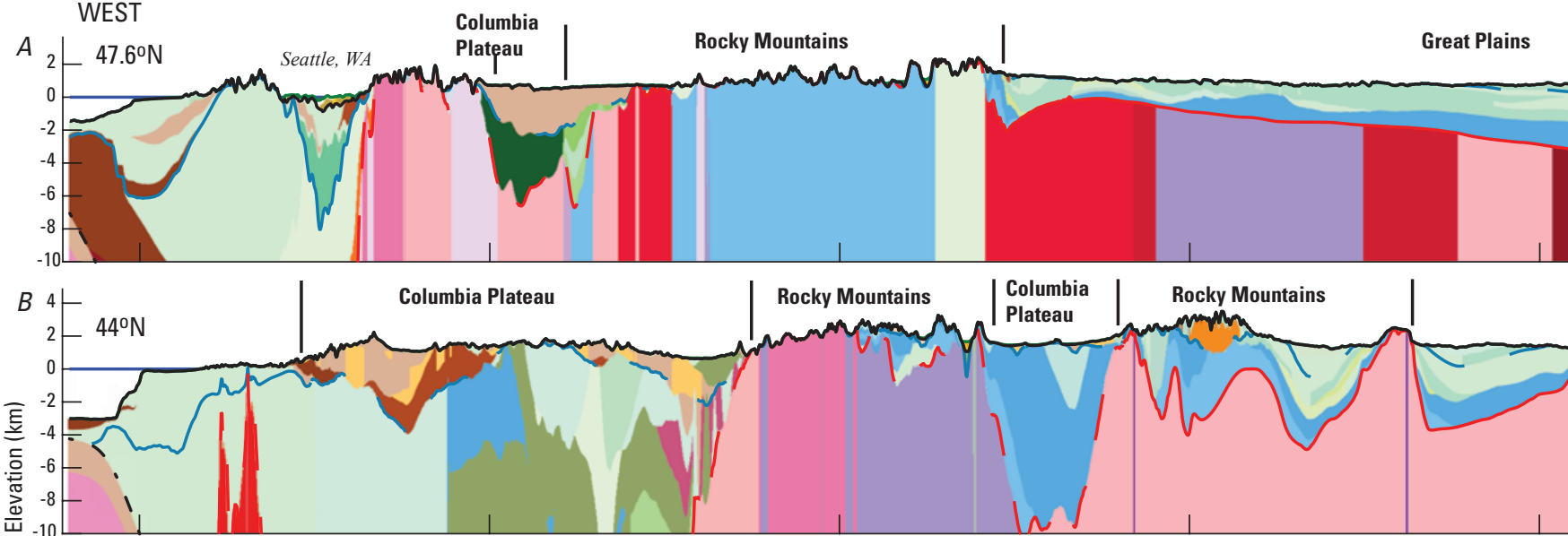
Plateau
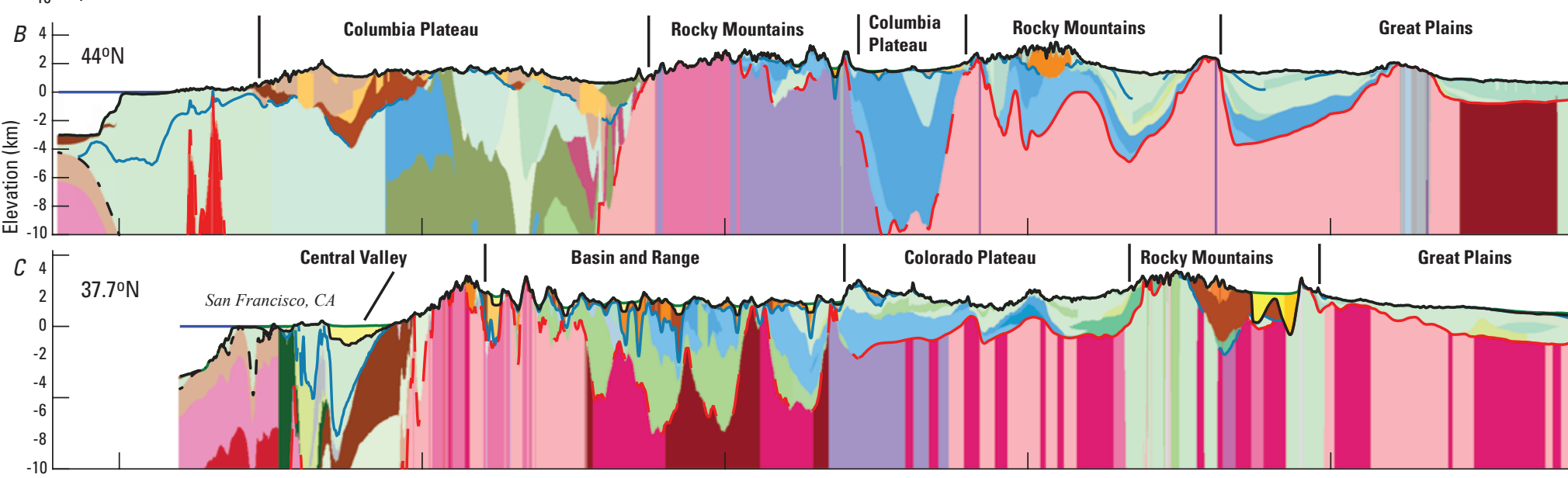

Great Plains

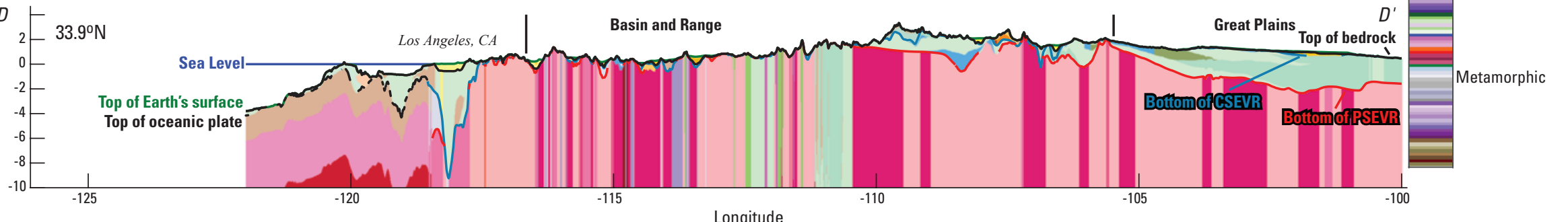

Figure 8. Cross-sections of subsurface lithology in the United States. Profile locations, from north to south, are shown in figure 6. The green line is the top of the Earth's surface, the blue line is sea level, the black line is the top of bedrock, the solid or dashed navy-blue line is the bottom of Cenozoic sedimentary and extrusive volcanic rocks (CSEVR), the solid or dashed red line is the bottom of Phanerozoic sedimentary and extrusive volcanic rocks (PSEVR), and the orange line is the top of the oceanic plate. Dashed lines indicate depths determined from the closest distance to the edge of either Cenozoic or Phanerozoic non-intrusive units. Younger rocks lying beneath older rocks are igneous intrusions. Vertical exaggeration approximately 20 times. 
sections are: $A-A^{\prime \prime}$, Washington to North Dakota through Seattle; $B-B^{\prime}$, Oregon to South Dakota through the Columbia Plateau; $C-C^{\prime}$, San Francisco, California, to western Kansas, crossing through the Central Valley of California, the Basin and Range in Nevada and Utah, the Colorado Plateau in Utah and Colorado, and across the Rockies in Colorado into the Great Plains; and finally, $D-D^{\prime}$, Los Angeles, California, to Texas, passing through the southern Basin and Range and Great Plains.

Significant geologic complexity exists in the geologic framework in the Basin and Range province of the WUS and simplifies considerably moving east of the Rocky Mountains. Algorithmically, the decrease in complexity is due to a decrease in the range of geologic units at the Earth's surface, which translates into less variability in the subsurface. To some extent, this is an artefact of the processing where geologic units that do not crop out at the surface are not modeled in the subsurface.

Other artefacts from the algorithms used to produce the geologic model, as discussed in the section "Lithology and Age of Subsurface Layers," can also be seen in these cross sections. Igneous intrusions and geologic units in the Proterozoic and Archean basement extend vertically to the mid crust. Rock types of the same age meet at vertical contacts. For example, in the uppermost cross section $A-A^{\prime \prime}$, near $-105.5^{\circ} \mathrm{W}$, Late Cretaceous shale to the west sits adjacent to Late Cretaceous sandstone to the east (figs. 7 and 8 ).

To gain a better appreciation for more local features, cross sections through Seattle, Washington, highlighting the Seattle Basin and subducting Juan de Fuca plate (section $A-A$ ) are presented in figure 9. Large earthquakes have occurred at the interface between the Juan de Fuca and the North American plates at the top of the subducting slab, and the geometry of overlying rocks and sediment are expected to contribute to significantly greater earthquake ground motions in the Seattle Basin (Frankel and others, 2007). Relative to the current seismic model for Cascadia (Stephenson and others, 2017), originally published in 2007 with updates published in 2017, the geologic framework presented here includes surface topography, an updated map of the depth to bedrock (Shah and Boyd, 2018), primarily from Eungard (2014) in the Puget Sound, an updated map of the top of the subducting plate (Hayes and others, 2018), and additional lithologic layering where beneath Seattle, Pleistocene glacial drift overlies Miocene sandstone and Eocene basalt and arkose within the basin, which overlies Cretaceous argillite in the basement. These improvements may lead to more accurate estimates of earthquake ground motion in the Seattle area but will at least result in a greater appreciation of the epistemic uncertainty in modeled ground motions.

Geologic profiles at locations not coinciding with grid nodes are estimated using cubic interpolation. More specifically, a geologic profile is constructed using the 4 neighbors surrounding the point of interest, and layer boundaries for the layers within this profile are extracted from each of the 16 neighboring grid nodes. Cubic interpolation is then applied to the elevations of these boundaries yielding layer boundaries at the location of interest. The effect of this smoothing is minimal in figures 7 and 8 but has a much greater effect in figure 9.

\section{Discussion}

The models and methods presented in this report result in a geologic framework that produces 3D subsurface geology that is very similar to other geologic models. This is understandable given that, for example, surfaces within the Bay Area (Aagaard and others, 2010) and southern California (Shaw and others, 2015) models are used as input for the NCM, and similar input surfaces are used both in the NCM and in the Seattle model (Stephenson and others, 2017). There are important differences, however. For example, the Bay Area model includes faults that separate geologic units along near-vertical boundaries.

It is important to recognize the limitations of the NCM geologic framework, both in the underlying models and in the algorithms used to build the framework. These limitations are partly responsible for observed and expected differences with existing data and models.

For instance, while application of the Pelletier and others (2016) ASST model helps to achieve continuity in this surface across the boundary of the Shah and Boyd (2018) model, bedrock depths from the state compilations in Missouri, Tennessee, and Kentucky appear deeper (fig. 3). Adding the Pelletier and others (2016) regolith model helps to resolve this discrepancy, which suggests that the difference may be related to regolith above more competent rock not contained in the average soil and sediment thickness model. Additional research is recommended in Phase 2 of the project to better understand this issue. It is therefore possible that the next version of the NCM bedrock model in the WUS and CEUS may be deeper in some areas after resolving this discrepancy.

Further, the Pelletier and others (2016) ASST model is capped at $50 \mathrm{~m}$. Shah and Boyd (2018) resolved this issue by removing capped values and then using minimum curvature to deepen these areas. As well, bedrock in other areas in the WUS may be too shallow but not necessarily hit the 50-m cap. In Oregon, for example, these areas include the Grande Ronde Basin, the Ontario-Vale area, the Klamath Basin, Goose Lake, Summer Lake, Alvord Basin grabens, and the Harney Basin. This may be partially reflected in the fact that the Pelletier and others (2016) models were calibrated primarily with CEUS well data. Differences between CEUS and WUS basin tectonics and geometry may also play a part. 

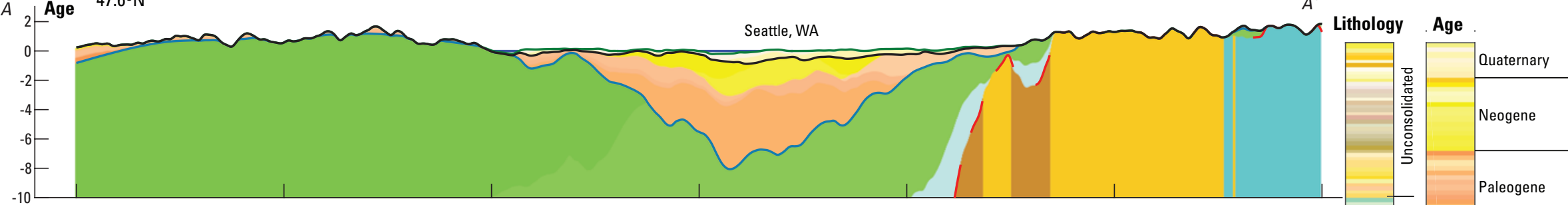

$A_{2} 2$ Lithology

Top of Earth's surface Seattle, WA

A
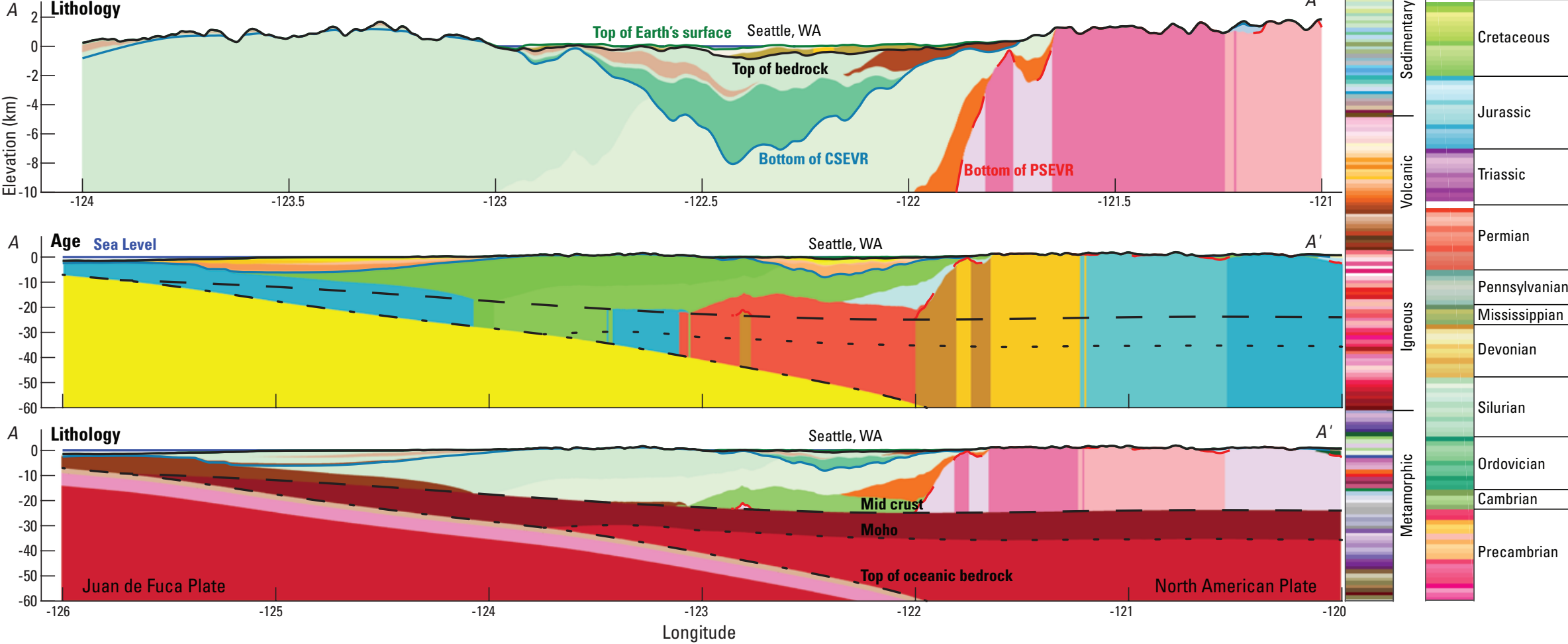

Figure 9. Cross sections through Seattle, Washington, highlighting the Seattle Basin in the upper two cross sections and the subducting Juan de Fuca plate in the lower two. The green line is the top of the Earth's surface, the blue line is sea level, the black line is the top of bedrock, the navyblue line is the bottom of Cenozoic sedimentary and extrusive volcanic rocks (CSEVR), the dashed red line is the bottom of Phanerozoic sedimentary and extrusive volcanic rocks (PSEVR), the dashed black line is the mid crustal contact, the black dotted line is the Moho, and the orange line is the top of the Juan de Fuca plate. Dashed Cenozoic and Phanerozoic SEVR indicate the regions where depth was determined by the closest distance method. Vertical exaggeration in the upper two cross sections is 3 times; there is no vertical exaggeration in the lower two cross sections. 
Like the bedrock model, some discrepancies exist between the basement model presented here and the true thickness of Cenozoic SEVR. For example, the depth to basement (thickness of Tertiary sediments) in the Big Hole valley in western Montana is up to $5 \mathrm{~km}$ thick as confirmed by drilling (Constenius, 1988), but the model from Shah and Boyd (2018), based on a broader regional gravity study in this area, is about half as deep.

Algorithmically, the method of producing subsurface geology presented here may produce reasonable stratigraphic sections in that younger depositional units lie above older, but the methods can lead to obvious problems. As stated previously, two lithologies of the same age will meet at a vertical boundary in the subsurface. In reality, this boundary is likely not vertical but may dip if one lithology is distinctly older than the other, or it may interfinger as the Earth's surface conditions oscillate during deposition (for example, transgressions and regressions in sea level). Furthermore, the lateral position of this boundary is highly uncertain, as it was determined by the most basic interpolation method of nearest neighbors.

Another problem is that igneous intrusions extend vertically in this model but may have come up through the crust along a tortuous path and leave a series of unmodeled dikes and sills. Consequently, the subsurface position of intrusive and neighboring units becomes very uncertain with increasing distance from the outcrop.

With respect to unmodeled features, the method of extrapolation applied here may miss geologic units that do not crop out but are surely present in the subsurface. Insertion of 'missing' units will only go so far. Moreover, faults and the discontinuities in geology produced by them, as is considered, for example, in the Bay Area model, are also not explicitly modeled, except as present as discontinuities in depth to bedrock and basement maps.

These issues can be addressed in future refinements of the NCM by incorporating additional detailed studies, for example, hydrogeologic studies, where researchers have been able to use a variety of direct and indirect methods to observe the subsurface and build better constrained 3D geologic models. These more detailed regional models could, in fact, be inserted directly into the NCM if rock age and type definitions as well as unit contact elevations at the boundary are consistent between the NCM and the regional model.

In terms of seismic hazard and ground motions from earthquakes, the greatest influence will be that of the shallow velocity gradient and the depth to bedrock where potentially large impedance contrasts between unconsolidated sediment and rock can trap a significant amount of seismic energy thereby increasing both shaking duration and amplitude. Impedance contrasts between various types of igneous and metamorphic rocks at greater depth are unlikely to be as significant for the purpose of estimating earthquake ground motion. However, long wavelength variations in velocity, attenuation, and density from perturbations in composition and temperature will have a second order effect on ground motion hazard, through path-dependent seismic attenuation, geometric spreading, and "the Moho Bounce" observed in earthquake ground motions at roughly 50 to $100 \mathrm{~km}$ epicentral distance in the CEUS.

These assertions regarding aspects of the model that influence ground motions will need to be tested to determine how much effort should be put into improving various parts of the geologic framework for the purpose of improving seismic hazard estimates. Furthermore, estimates of the uncertainty in model parameters must be part of this process to fully appreciate the sensitivity to model components.

\section{Conclusions}

The 3D geologic framework for the NCM in the WUS is composed of geologic units defined by 164 possible ages (table 1.1) and 209 possible lithologies (table 2.1). Continental upper crustal geology is extrapolated from geology at or near the Earth's surface constrained by maps of basement geology and the depth to bedrock and basement. Lower crustal and lithospheric mantle geology is assumed to have a pyroxenite and peridotite composition, respectively, with depths provided by published models. Oceanic geology is a simpler multi-layer model consisting of sediment, sedimentary rock, basalt, gabbro, and peridotite that subducts beneath the Pacific Northwest.

The framework is limited in several ways including: (1) mapping of the subsurface extent of geologic units is obtained by nearest neighbor interpolation; (2) two lithologies of the same age will meet along a vertical planar boundary; and (3) the framework does not account explicitly for geologic units that do not crop out, realistic geometries of subsurface intrusive bodies (dikes, sills, and magma chambers), or the effects of faults on the continuity of subsurface bodies.

Many of the limitations of this framework are expected to result in secondary influences on earthquake ground motion. The primary influence will result from the depth to bedrock, which, while uncertain in some areas, is adequately modeled in much of the WUS. This framework is a key component of the NCM and can lead to improved estimates of earthquake ground motion and reduced risk from earthquakes. 


\section{References Cited}

Aagaard, B.T., Graves, R.W., Rodgers, A., Brocher, T.M., Simpson, R.W., Dreger, D., Petersson, N.A., Larsen, S.C., Ma, S., and Jachens, R.C., 2010, Ground motion modeling of Hayward fault scenario earthquakes, Part II-Simulation of long-period and broadband ground motions: Bulletin of the Seismological Society of America, v. 100, no. 6, p. 2945-2977. [Also available at http://dx.doi.org/10.1785/0120090379.]

Boyd, O.S., 2019, 3D Geologic Framework for use with the U.S. Geological Survey National Crustal Model, Phase 1: Western United States: U.S. Geological Survey data release, https://doi.org/10.5066/P9SBQENM.

Branscombe, P., MacCormack, K.E., and Babakhani, M., 2017, 3D Provincial geological framework model of Alberta, version 1-Methodology: Alberta Energy Regulator (AER)/Alberta Geological Survey (AGS) Open-File Report 2017-09, 114 p., accessed August 22, 2018, at https://ags.aer.ca/publications/OFR_2017_09.html.]

Brown, G.C., and Mussett, A.E., 1981, The Inaccessible Earth: London, Allen and Unwin., 276 p.

Buehler, J.S., and Shearer, P.M., 2017, Uppermost mantle seismic velocity structure beneath USArray: Journal of Geophysical Research, v. 122, p. 436-448, accessed October 18, 2018, at https://doi.org/10.1002/2016JB013265.]

Constenius, K.N., 1988, Structural configuration of the Kishenehn Basin delineated by geophysical methods, northwestern Montana and southeastern British Columbia: The Mountain Geologist, v. 25, p. 13-28. [Also available at http://archives.datapages. com/data/rmag/mg/1988/constenius.html.]

Dickinson, W.R., 2004, Evolution of the North American Cordillera: Annual Review of Earth and Planetary Sciences, v. 32, no. 1, p. 13-45. [Also available at https://doi.org/10.1146/annurev.earth.32.101802.120257.]

Eungard, D.W., 2014, Models of bedrock elevation and unconsolidated sediment thickness in the Puget Lowland, Washington: Washington Division of Geology and Earth Resources Open File Report v. 2014-04, p. 26 p., accessed June 22, 2016 , at http://www.dnr.wa.gov/publications/ger_ofr2014-04_puget_lowland_depth_to_bedrock.zip.

Fenneman, N.M., and Johnson, D.W., 1946, Physical divisions of the United States: U.S. Geological Survey. [Also available at https://store.usgs.gov/assets/MOD/StoreFiles/PDFs_2013/101215_US_Physical_Divisions_7MM_1946.pdf.]

Frankel, A.D., Stephenson, W.J., Carver, D.L., Williams, R.A., Odum, J.K., and Rhea, S., 2007, Seismic hazard maps for Seattle, Washington, incorporating 3D sedimentary basin effects, nonlinear site response, and rupture directivity: U.S. Geological Survey Open-File Report 2007-1175, 77 p., 3 pl., scale 1:25,000. [Also available at https://doi.org/10.3133/ofr20071175.]

Frezon, S.I., compiler, Finn, T.M., and Lister, J.H., 1983, Total thickness of sedimentary rocks in the conterminous United States: U.S. Geological Survey Open-File Report 83-920, 1 pl. [Also available at https://doi.org/10.3133/ofr83920.]

Garrity, C.P., and Soller, D.R., 2009, Database of the geologic map of North America; adapted from the map by J.C. Reed, Jr. and others (2005): U.S. Geological Survey Data Series 424. [Also available at https://doi.org/10.3133/ds424.]

General Bathymetric Chart of the Oceans (GEBCO), 2018, GEBCO 2014 grid, version 20150318: United Nations Educational, Scientific and Cultural Organization (UNESCO), General Bathymetric Chart of the Oceans, accessed on April 19, 2018 at https://www.gebco.net/data_and_products/gridded_bathymetry_data/gebco_one_minute_grid/.

Gutentag, E.D., Heimes, F.J., Krothe, N.C., Luckey, R.R., and Weeks, J.B., 1984, Geohydrology of the High Plains Aquifer in parts of Colorado, Kansas, Nebraska, New Mexico, Oklahoma, South Dakota, Texas, and Wyoming: U.S. Geological Survey Professional Paper 1400-B, 63 p. [Also available at https://doi.org/10.3133/pp1400B.]

Hayes, G.P., Moore, G.L., Portner, D.E., Hearne, M., Flamme, H., Furtney, M., and Smoczyk, G.M., 2018, Slab2, a comprehensive subduction zone geometry model: Science, v. 362, issue 6410, accessed September 25, 2018, at https://doi.org/10.1126/ science.aat4723.

Horton, J.D., 2017, The State Geologic Map Compilation (SGMC) geodatabase of the conterminous United States (ver. 1.1, August 2017): U.S. Geological Survey data release, accessed July 7, 2018, at https://doi.org/10.5066/F7WH2N65.

Horton, J.D., San Juan, C.A., and Stoeser, D.B., 2017, The State Geologic Map Compilation (SGMC) geodatabase of the conterminous United States (ver. 1.1, August 2017): U.S. Geological Survey Data Series 1052, 46 p., accessed July 7, 2018, at https://doi.org/10.3133/ds1052. 
International Commission on Stratigraphy, 2016, International chronostratigraphic chart v. 2016/10: International Commission on Stratigraphy, accessed July 6, 2018, at http://stratigraphy.org/ICSchart/ChronostratChart2016-10.pdf.

Jachens, R.C., and Moring, B.C., 1990, Maps of the thickness of Cenozoic deposits and the isostatic residual gravity over basement for Nevada: U.S. Geological Survey Open-File Report 90-404, 15 p. [Also available at https://doi.org/10.3133/ ofr90404.]

Johnson, B.R., 2002, Draft-Geologic map unit classification, ver. 6.1, A proposed hierarchical classification of units for digital geologic maps: North American Geologic Map Data Model (NADM), https://ngmdb.usgs.gov/www-nadm/dmdt/pdf/lithclass61.pdf.

Marshak, S., Domrois, S., Abert, C., Larson, T., Pavlis, G., Hamburger, M., Yang, X., Gilbert, H., and Chen, C., 2017, The basement revealed-Tectonic insight from a digital elevation model of the Great Unconformity, USA cratonic platform: Geology, v. 45, no. 5, p. 391-394, accessed on February 2, 2018, at https://doi.org/10.1130/G38875.1.

Mooney, W.D., and Kaban, M.K., 2010, The North American upper mantle-Density, composition, and evolution: Journal of Geophysical Research, Solid Earth, v. 115, issue B12, 24 p. [Also available at https://doi.org/10.1029/2010JB000866.]

Moyer, L.A., Hastings, J.T., and Raines, G.L., 2005, Methods to create ArcMap styles with examples for lithology and time: U.S. Geological Survey Open-File Report 2005-1314, 21 p. [Also available at https://doi.org/10.3133/ofr20051314.]

Müller, R.D., Sdrolias, M., Gaina, C., and Roest, W.R., 2008, Age, spreading rates, and spreading asymmetry of the world's ocean crust: Geochemistry, Geophysics, Geosystems, v. 9, issue 4, 19 p. [Also available at https://doi. org/10.1029/2007GC001743.]

Pasyanos, M.E., Masters, T.G., Laske, G., and Ma, Z., 2014, LITHO1.0 - An updated crust and lithospheric model of the Earth: Journal of Geophysical Research, Solid Earth, v. 119, issue 3, p. 2153-2173, accessed March 16, 2018, at https://doi. org/10.1002/2013JB010626.]

Pelletier, J.P., Broxton, P.D., Hazenberg, P., Zeng, X., Troch, P.A., Niu, G.-Y., Williams, Z., Brunke, M.A., and Gochis, D., 2016, A gridded global data set of soil, immobile regolith, and sedimentary deposit thicknesses for regional and global land surface modeling: Journal of Advances in Modeling Earth Systems, v. 8, issue 1, p. 41-65, accessed on June 26, 2017, at https://doi. org/10.1002/2015MS000526.

Saltus, R.W., 1993, Upper crustal structure beneath the Columbia River Basalt Group, Washington - Gravity interpretation controlled by borehole and seismic studies: Geological Society of America Bulletin, v. 105, p. 1247-1259. [Also available at https://doi.org/10.1130/0016-7606(1993)105\%3C1247:UCSBTC\%3E2.3.CO;2.]

Saltus, R.W., and Jachens, R.C., 1995, Gravity and basin-depth maps of the Basin and Range Province, western United States: U.S. Geological Survey Geophysical Investigation Map 1012, scale 1:2,5000,000. [Also available at https://doi.org/10.3133/ gp1012.]

Shah, A.K., and Boyd, O.S., 2018, Depth to basement and thickness of unconsolidated sediments for the western United States-Layers of the USGS National Crustal Model, version 1.0: U.S. Geological Survey Open-File Report 2018-1115, 13 p., accessed July 11, 2018, at https://doi.org/10.3133/ofr20181115.

Shaw, J.H., Plesch, A., Tape, C., Suess, M.P., Jordan, T.H., Ely, G., Hauksson, E., Tromp, J., Tanimoto, T., Graves, R., Olsen, K., Nicholson, C., Maechling, P.J., Rivero, C., Lovely, P., Brankman, C.M., and Munster, J., 2015, Unified structural representation of the southern California crust and upper mantle: Earth and Planetary Science Letters, v. 415, p. 1-15, accessed March 23, 2017, at https://doi.org/10.1016/j.epsl.2015.01.016.

Shen, W., and Ritzwoller, M.H., 2016, Crustal and uppermost mantle structure beneath the United States: Journal of Geophysical Research, Solid Earth, v. 121, issue 6, p. 4306-4342, accessed November 29, 2016, at https://doi.org/10.1002/2016JB012887.

Sowers, T., and Boyd, O.S., 2019, Petrologic and mineral physics database for use with the USGS National Crustal Model: U.S. Geological Survey Open-File Report 2019-1035, 17 p., https://doi.org/10.3133/ofr20191035.

Stephenson, W.J., Reitman, N.G., and Angster, S.J., 2017, P- and S-wave velocity models incorporating the Cascadia subduction zone for 3D earthquake ground motion simulations, version 1.6-Update for Open-File Report 2007-1348: U.S. Geological Survey Open-File Report 2017-1152, 17 p., accessed September 25, 2018, https://doi.org/10.3133/ofr20171152. 
Weatherall, P., Marks, K.M., Jakobsson, M., Schmitt, T., Tani, S., Arndt, J.E., Rovere, M., Chayes, D., Ferrini, V., and Wigley, R., 2015, A new digital bathymetric model of the world's oceans: Earth and Space Science, v. 2, p. 331-345, accessed April 19, 2018, at https://doi.org/10.1002/2015EA000107.

Whitmeyer, S.J., and Karlstrom, K.E., 2007, Tectonic model for the Proterozoic growth of North America: Geosphere, v. 3 , no. 4, p. 220-259, accessed February 8, 2019, at https://doi.org/10.1130/GES00055.1.

Whittaker, J., Goncharov, A., Williams, S., Müller, R.D., and Leitchenkov, G., 2013, Global sediment thickness dataset updated for the Australian-Antarctic Southern Ocean: Geochemistry, Geophysics, Geosystems, v. 14, issue 8, p. 3297-3305, accessed January 5, 2017, at https://doi.org/10.1002/ggge.20181.

Wilshire, H.G., 1990, Lithology and evolution of the crust-mantle boundary region in the southwestern Basin and Range Province: Journal of Geophysical Research, v. 95, issue B1, p. 649-665. [Also available at https://doi.org/10.1029/ JB095iB01p00649.] 


\section{Appendix 1. Age Dictionary and Mapping}

Table 1.1. Age dictionary and indexes with alternate names present in either the State Geologic Map Compilation (SGMC, Horton, 2017; Horton and others, 2017) or Geologic Map of North America (GMNA, Garrity and Soller, 2009) databases. Dictionary based on that in Horton and others (2017).

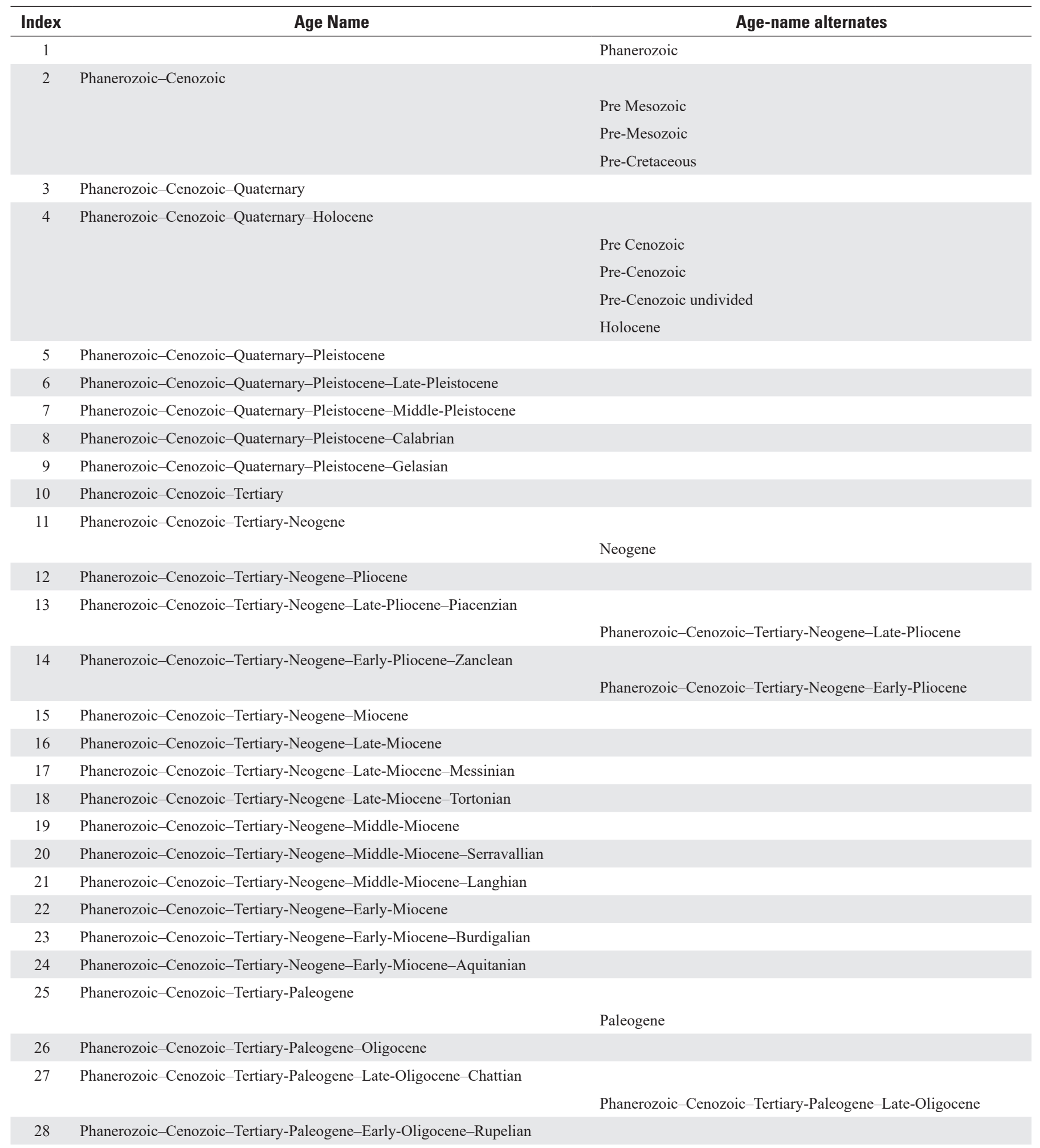


Table 1.1. Age dictionary and indexes with alternate names present in either the State Geologic Map Compilation (SGMC, Horton, 2017; Horton and others, 2017) or Geologic Map of North America (GMNA, Garrity and Soller, 2009) databases. Dictionary based on that in Horton and others (2017). - Continued

\begin{tabular}{|c|c|c|}
\hline Index & Age Name & Age-name alternates \\
\hline 29 & Phanerozoic-Cenozoic-Tertiary-Paleogene-Eocene & \\
\hline \multirow{2}{*}{30} & & Upper Eocene \\
\hline & & Phanerozoic-Cenozoic-Tertiary-Paleogene-Late-Eocene \\
\hline 31 & & Middle Eocene \\
\hline 32 & Phanerozoic-Cenozoic-Tertiary-Paleogene-Middle-Eocene-Bartonian & \\
\hline 33 & Phanerozoic-Cenozoic-Tertiary-Paleogene-Middle-Eocene-Lutetian & \\
\hline \multirow[t]{2}{*}{34} & Phanerozoic-Cenozoic-Tertiary-Paleogene-Early-Eocene-Ypresian & \\
\hline & & Lower Eocene \\
\hline 36 & & Phanerozoic-Cenozoic-Tertiary-Paleogene-Late-Paleocene \\
\hline 37 & Phanerozoic-Cenozoic-Tertiary-Paleogene-Middle-Paleocene-Selandian & \\
\hline \multirow[t]{2}{*}{38} & Phanerozoic-Cenozoic-Tertiary-Paleogene-Early-Paleocene-Danian & \\
\hline & & Phanerozoic-Cenozoic-Tertiary-Paleogene-Early-Paleocene \\
\hline 39 & Phanerozoic-Mesozoic & \\
\hline 40 & Phanerozoic-Mesozoic-Cretaceous & \\
\hline 41 & Phanerozoic-Mesozoic-Cretaceous-Late-Cretaceous & \\
\hline
\end{tabular}

$\begin{array}{ll}42 & \text { Phanerozoic-Mesozoic-Cretaceous-Late-Cretaceous-Maastrichtian } \\ 43 & \text { Phanerozoic-Mesozoic-Cretaceous-Late-Cretaceous-Campanian } \\ 44 & \text { Phanerozoic-Mesozoic-Cretaceous-Late-Cretaceous-Santonian } \\ 45 & \text { Phanerozoic-Mesozoic-Cretaceous-Late-Cretaceous-Coniacian } \\ 46 & \text { Phanerozoic-Mesozoic-Cretaceous-Late-Cretaceous-Turonian } \\ 47 & \text { Phanerozoic-Mesozoic-Cretaceous-Late-Cretaceous-Cenomanian }\end{array}$

Upper Cretaceous

Late Cretaceous

\begin{tabular}{|c|c|c|}
\hline & & $\begin{array}{l}\text { Mid-Cretaceous } \\
\text { Middle Cretaceous }\end{array}$ \\
\hline 48 & Phanerozoic-Mesozoic-Cretaceous-Early-Cretaceous & $\begin{array}{l}\text { Lower Cretaceous } \\
\text { Early Cretaceous }\end{array}$ \\
\hline 49 & Phanerozoic-Mesozoic-Cretaceous-Early-Cretaceous-Albian & \\
\hline 50 & Phanerozoic-Mesozoic-Cretaceous-Early-Cretaceous-Aptian & \\
\hline 51 & Phanerozoic-Mesozoic-Cretaceous-Early-Cretaceous-Barremian & \\
\hline 52 & Phanerozoic-Mesozoic-Cretaceous-Early-Cretaceous-Hauterivian & \\
\hline 53 & Phanerozoic-Mesozoic-Cretaceous-Early-Cretaceous-Valanginian & \\
\hline 54 & Phanerozoic-Mesozoic-Cretaceous-Early-Cretaceous-Berriasian & \\
\hline 55 & Phanerozoic-Mesozoic-Jurassic & \\
\hline 56 & Phanerozoic-Mesozoic-Jurassic-Late-Jurassic & \\
\hline & & $\begin{array}{l}\text { Upper Jurassic } \\
\text { Late Jurassic }\end{array}$ \\
\hline
\end{tabular}


Table 1.1. Age dictionary and indexes with alternate names present in either the State Geologic Map Compilation (SGMC, Horton, 2017; Horton and others, 2017) or Geologic Map of North America (GMNA, Garrity and Soller, 2009) databases. Dictionary based on that in Horton and others (2017). - Continued

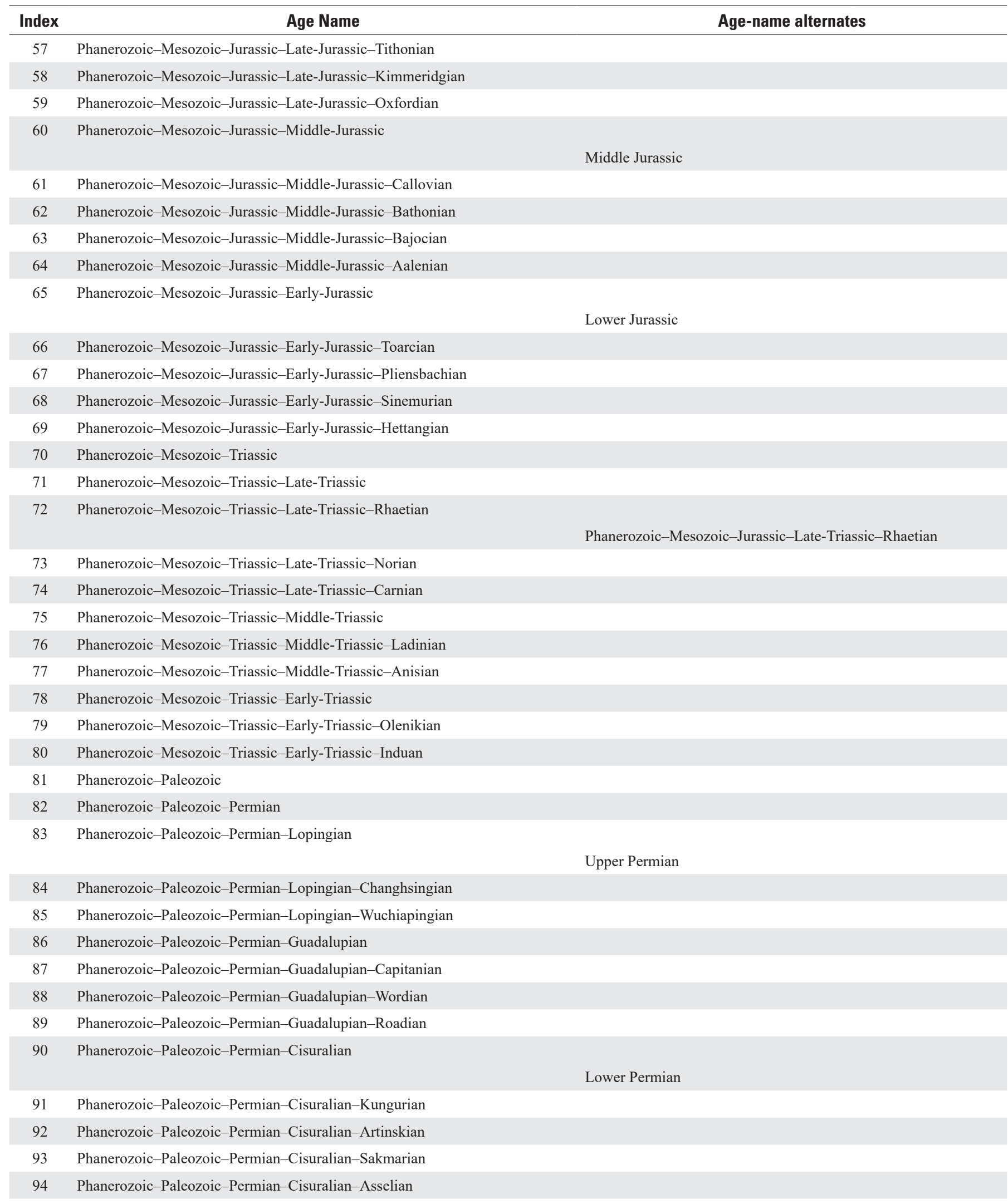


Table 1.1. Age dictionary and indexes with alternate names present in either the State Geologic Map Compilation (SGMC, Horton, 2017; Horton and others, 2017) or Geologic Map of North America (GMNA, Garrity and Soller, 2009) databases. Dictionary based on that in Horton and others (2017).-Continued

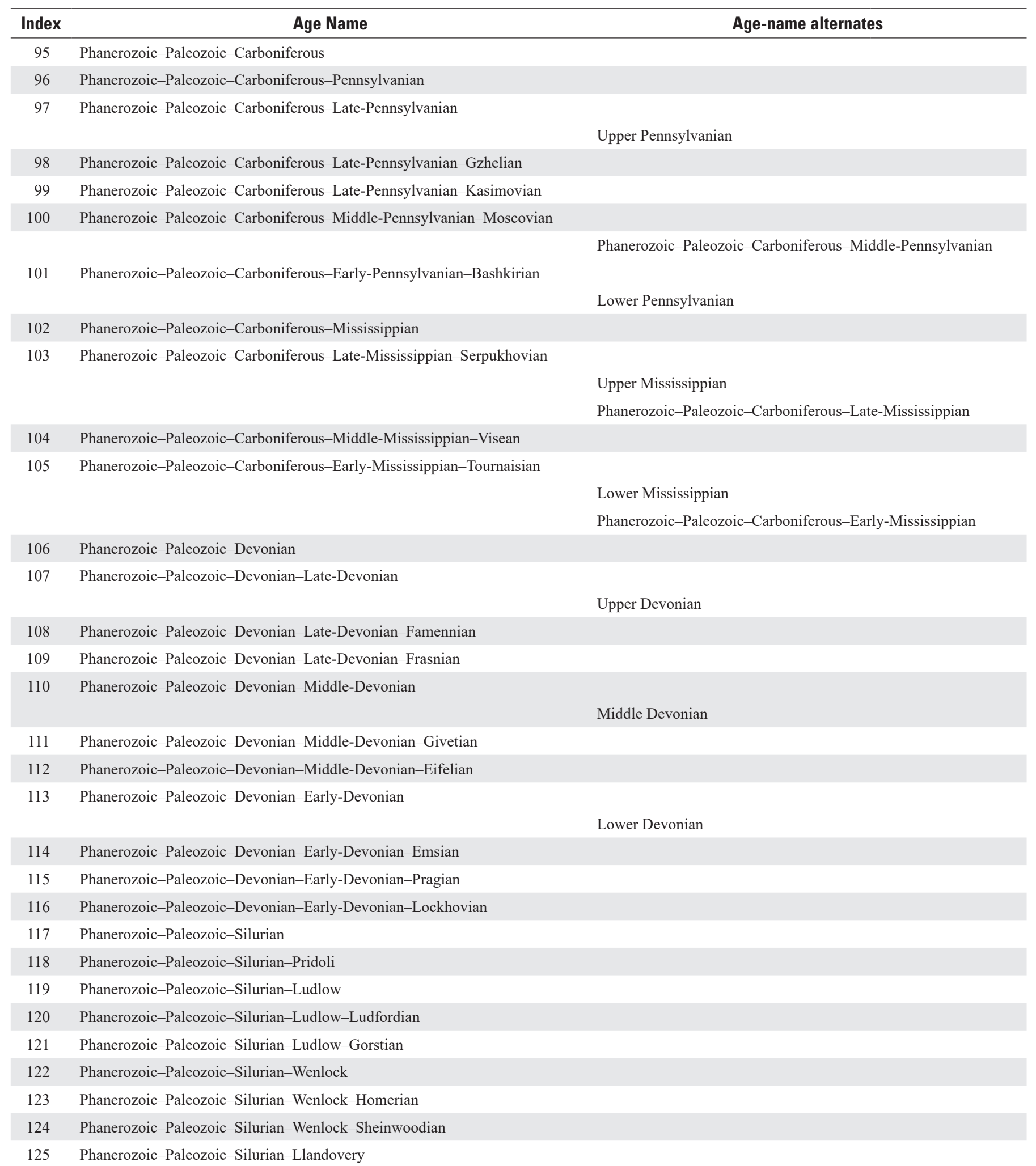

Lower Silurian

126 Phanerozoic-Paleozoic-Silurian-Llandovery-Telychian 
Table 1.1. Age dictionary and indexes with alternate names present in either the State Geologic Map Compilation (SGMC, Horton, 2017; Horton and others, 2017) or Geologic Map of North America (GMNA, Garrity and Soller, 2009) databases. Dictionary based on that in Horton and others (2017). - Continued

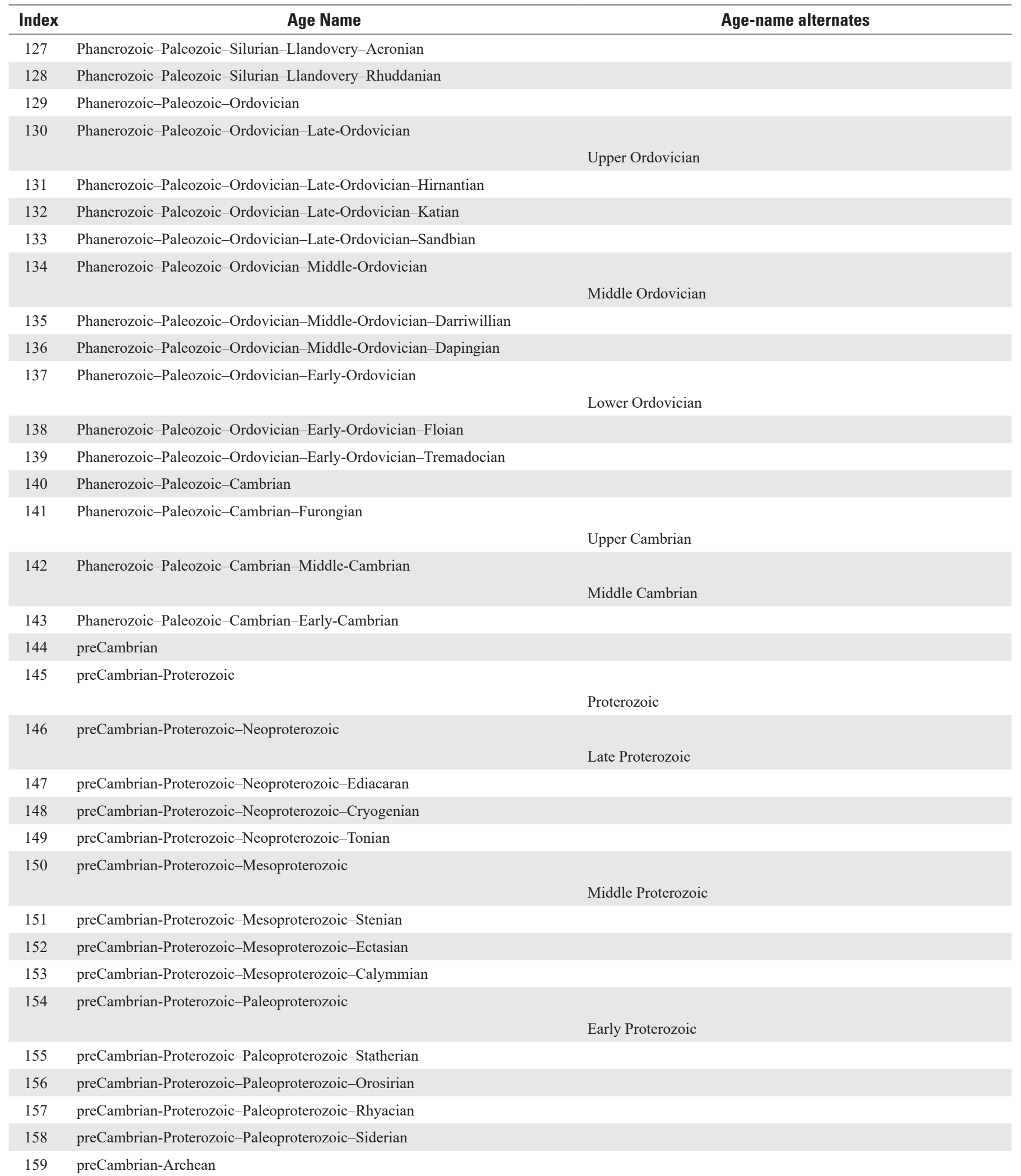


Table 1.1. Age dictionary and indexes with alternate names present in either the State Geologic Map Compilation (SGMC, Horton, 2017; Horton and others, 2017) or Geologic Map of North America (GMNA, Garrity and Soller, 2009) databases. Dictionary based on that in Horton and others (2017).-Continued

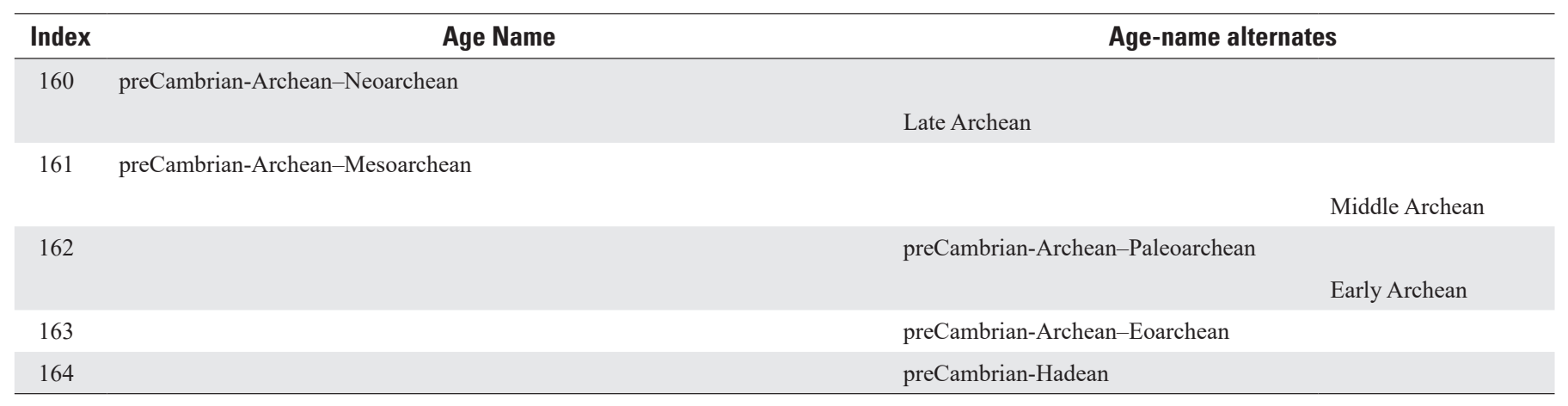




\section{Appendix 2. Lithology Dictionary and Mapping}

Table 2.1. Lithology dictionary and indexes with alternate names present in either the State Geologic Map Compilation (SGMC, Horton, 2017; Horton and others, 2017) or Geologic Map of North America (GMNA, Garrity and Soller, 2009) databases. Dictionary based on the Geologic Map Unit Classification, version 6.1, from Johnson (2002).

\begin{tabular}{|c|c|c|}
\hline Index & Rock type & Rock type alternates \\
\hline \multirow[t]{3}{*}{1} & Unconsolidated material & \\
\hline & & Unconsolidated deposit \\
\hline & & Unconsolidated \\
\hline \multirow[t]{2}{*}{2} & Alluvium & \\
\hline & & Alluvial deposits \\
\hline \multirow[t]{2}{*}{3} & Silt & \\
\hline & & Fine detrital \\
\hline \multirow[t]{2}{*}{4} & Sand & \\
\hline & & Coarse detrital \\
\hline 5 & Flood plain & \\
\hline \multirow[t]{2}{*}{6} & Gravel & \\
\hline & & Boulders \\
\hline \multirow[t]{2}{*}{7} & Levee & \\
\hline & & Dam \\
\hline 8 & Delta & \\
\hline 9 & Alluvial fan & \\
\hline \multirow[t]{2}{*}{10} & Alluvial terrace & \\
\hline & & Terrace deposits \\
\hline \multirow[t]{2}{*}{11} & Lake or marine sediment & \\
\hline & & Lake or marine deposit (non-glacial) \\
\hline 12 & Playa & \\
\hline 13 & Mud flat & \\
\hline 14 & Beach sand & \\
\hline 15 & Terrace & \\
\hline \multirow[t]{2}{*}{16} & Eolian material & \\
\hline & & Eolian \\
\hline 17 & Dune sand & \\
\hline 18 & Sand sheet & \\
\hline 19 & Loess & \\
\hline 20 & Volcanic ash & \\
\hline 21 & Mass wasting material & \\
\hline 22 & Colluvium & \\
\hline 23 & Mudflow & \\
\hline 24 & Lahar & \\
\hline 25 & Debris flow & \\
\hline 26 & Landslide & \\
\hline 27 & Talus & \\
\hline
\end{tabular}


Table 2.1. Lithology dictionary and indexes with alternate names present in either the State Geologic Map Compilation (SGMC, Horton, 2017; Horton and others, 2017) or Geologic Map of North America (GMNA, Garrity and Soller, 2009) databases. Dictionary based on the Geologic Map Unit Classification, version 6.1, from Johnson (2002).-Continued

\begin{tabular}{|c|c|c|}
\hline Index & Rock type & Rock type alternates \\
\hline \multirow[t]{2}{*}{28} & Glacial drift & \\
\hline & & Glacial deposits \\
\hline 29 & Till & \\
\hline 30 & Moraine & \\
\hline 31 & Stratified glacial sediment & \\
\hline 32 & Glacial outwash sediment & \\
\hline 33 & Outwash & \\
\hline 34 & Sub/supra glacial sediment & \\
\hline \multirow[t]{2}{*}{35} & Glaciolacustrine sediment & \\
\hline & & Glaciolacustrine \\
\hline 36 & Glacial marine sediment & \\
\hline \multirow[t]{2}{*}{37} & Biogenic material & \\
\hline & & Biogenic sediment \\
\hline 38 & Peat & \\
\hline 39 & Coral & \\
\hline 40 & Residuum & \\
\hline \multirow[t]{4}{*}{41} & Clay & \\
\hline & & Clay or mud \\
\hline & & Mud \\
\hline & & Marl \\
\hline \multirow[t]{2}{*}{42} & Sedimentary rock & \\
\hline & & Sedimentary \\
\hline \multirow[t]{2}{*}{43} & Clastic rock & \\
\hline & & Clastic \\
\hline 44 & Mudstone & \\
\hline \multirow[t]{2}{*}{45} & Claystone & \\
\hline & & Marlstone \\
\hline 46 & Bentonite & \\
\hline \multirow[t]{2}{*}{47} & Shale & \\
\hline & & Phosphatic shale \\
\hline 48 & Black shale & \\
\hline 49 & Oil shale & \\
\hline 50 & Argillite & \\
\hline \multirow[t]{3}{*}{51} & Siltstone & \\
\hline & & Siltstone mudstone \\
\hline & & Diatomite \\
\hline \multirow[t]{2}{*}{52} & Fine grained mixed clastic rock & \\
\hline & & Fine grained mixed clastic \\
\hline \multirow[t]{2}{*}{53} & Sandstone & \\
\hline & & Sandstone mudstone \\
\hline
\end{tabular}


Table 2.1. Lithology dictionary and indexes with alternate names present in either the State Geologic Map Compilation (SGMC, Horton, 2017; Horton and others, 2017) or Geologic Map of North America (GMNA, Garrity and Soller, 2009) databases. Dictionary based on the Geologic Map Unit Classification, version 6.1, from Johnson (2002).-Continued

\begin{tabular}{|c|c|c|}
\hline Index & Rock type & Rock type alternates \\
\hline 54 & Arenite & \\
\hline 55 & Orthoquartzite & \\
\hline 56 & Calcarenite & \\
\hline 57 & Arkose & \\
\hline 58 & Wacke & \\
\hline 59 & Graywacke & \\
\hline \multirow[t]{3}{*}{60} & Medium grained mixed clastic rock & \\
\hline & & Medium grained mixed clastic \\
\hline & & Mixed clastic \\
\hline \multirow[t]{3}{*}{61} & Conglomerate & \\
\hline & & Conglomerate sandstone \\
\hline & & Conglomerate mudstone \\
\hline 62 & Sedimentary breccia & \\
\hline \multirow[t]{2}{*}{63} & Coarse grained mixed clastic rock & \\
\hline & & Coarse grained mixed clastic \\
\hline 64 & Olistostrome & \\
\hline 65 & Melange & \\
\hline \multirow[t]{2}{*}{66} & Carbonate rock & \\
\hline & & Carbonate \\
\hline \multirow[t]{3}{*}{67} & Limestone & \\
\hline & & Coquina \\
\hline & & Chalk \\
\hline \multirow[t]{2}{*}{68} & Dolostone & \\
\hline & & Dolostone (dolomite) \\
\hline \multirow[t]{2}{*}{69} & Mixed carbonate/clastic rock & \\
\hline & & Mixed clastic/carbonate \\
\hline \multirow[t]{2}{*}{70} & Mixed volcanic/clastic rock & \\
\hline & & Mixed clastic/volcanic \\
\hline 71 & Phosphorite & \\
\hline \multirow[t]{2}{*}{72} & Chemical & \\
\hline & & Chemical sedimentary rock \\
\hline \multirow[t]{4}{*}{73} & Evaporite & \\
\hline & & Salt \\
\hline & & Anhydrite \\
\hline & & Gypsum \\
\hline 74 & Chert & \\
\hline 75 & Novaculite & \\
\hline \multirow[t]{2}{*}{76} & Banded iron formation & \\
\hline & & Iron formation \\
\hline 77 & Exhalite & \\
\hline
\end{tabular}


Table 2.1. Lithology dictionary and indexes with alternate names present in either the State Geologic Map Compilation (SGMC, Horton, 2017; Horton and others, 2017) or Geologic Map of North America (GMNA, Garrity and Soller, 2009) databases. Dictionary based on the Geologic Map Unit Classification, version 6.1, from Johnson (2002)._-Continued

\begin{tabular}{|c|c|c|}
\hline Index & Rock type & Rock type alternates \\
\hline \multirow[t]{2}{*}{78} & Coal & \\
\hline & & Lignite \\
\hline 79 & Mixed coal/clastic rock & \\
\hline \multirow[t]{5}{*}{80} & Volcanic rock & \\
\hline & & Volcanic rock (aphanitic) \\
\hline & & Volcanic \\
\hline & & Hypabyssal \\
\hline & & Undivided volcanic rocks \\
\hline 81 & Glassy volcanic rock & \\
\hline 82 & Obsidian & \\
\hline 83 & Vitrophyre & \\
\hline 84 & Pumice & \\
\hline \multirow[t]{2}{*}{85} & Pyroclastic rock & \\
\hline & & Pyroclastic \\
\hline 86 & Tuff & \\
\hline 87 & Welded tuff & \\
\hline 88 & Ash flow tuff & \\
\hline 89 & Ignimbrite & \\
\hline \multirow[t]{2}{*}{90} & Volcanic breccia & \\
\hline & & Volcanic breccia (agglomerate) \\
\hline 91 & Lava flow & \\
\hline 92 & Bimodal suite & \\
\hline \multirow[t]{6}{*}{93} & Felsic volcanic rock & \\
\hline & & Felsic volcanic \\
\hline & & Felsic hypabyssal \\
\hline & & Felsic rocks \\
\hline & & Felsic and intermediate rocks \\
\hline & & Felsite \\
\hline \multirow[t]{3}{*}{94} & Alkali feldspar rhyolite & \\
\hline & & Alkali rhyolite \\
\hline & & Hypabyssal felsic alkaline \\
\hline \multirow[t]{2}{*}{95} & Rhyolite & \\
\hline & & Hypabyssal rhyolite \\
\hline 96 & Rhyodacite & \\
\hline \multirow[t]{2}{*}{97} & Dacite & \\
\hline & & Hypabyssal dacite \\
\hline 98 & Alkali feldspar trachyte & \\
\hline \multirow[t]{3}{*}{99} & Trachyte & \\
\hline & & Hypabyssal trachyte \\
\hline & & Quartz trachyte \\
\hline
\end{tabular}


Table 2.1. Lithology dictionary and indexes with alternate names present in either the State Geologic Map Compilation (SGMC, Horton, 2017; Horton and others, 2017) or Geologic Map of North America (GMNA, Garrity and Soller, 2009) databases. Dictionary based on the Geologic Map Unit Classification, version 6.1, from Johnson (2002).-Continued

\begin{tabular}{|c|c|c|}
\hline Index & Rock type & Rock type alternates \\
\hline & & Hypabyssal quartz trachyte \\
\hline \multirow[t]{2}{*}{100} & Quartz latite & \\
\hline & & Hypabyssal quartz latite \\
\hline \multirow[t]{2}{*}{101} & Latite & \\
\hline & & Hypabyssal latite \\
\hline \multirow[t]{2}{*}{102} & Intermediate volcanic rock & \\
\hline & & Intermediate rocks \\
\hline 103 & Trachyandesite & \\
\hline \multirow[t]{3}{*}{104} & Andesite & \\
\hline & & Hypabyssal andesite \\
\hline & & Hypabyssal basaltic andesite \\
\hline \multirow[t]{6}{*}{105} & Mafic rock & \\
\hline & & Mafic rocks \\
\hline & & Mafic volcanic rock \\
\hline & & Mafic volcanic rocks \\
\hline & & Mafic volcanic \\
\hline & & Mafic hypabyssal \\
\hline 106 & Trachybasalt & \\
\hline \multirow[t]{3}{*}{107} & Basalt & \\
\hline & & Hypabyssal basalt \\
\hline & & Basaltic andesite \\
\hline 108 & Tholeiite & \\
\hline 109 & Hawaiite & \\
\hline \multirow[t]{3}{*}{110} & Alkaline basalt & \\
\hline & & Hypabyssal mafic alkaline \\
\hline & & Alkaline mafic rocks \\
\hline \multirow[t]{3}{*}{111} & Alkalic volcanic rock & \\
\hline & & Alkalic volcanic \\
\hline & & Alkaline rocks \\
\hline 112 & Phonolite & \\
\hline \multirow[t]{3}{*}{113} & Tephrite & \\
\hline & & Tephrite (basanite) \\
\hline & & Basanite \\
\hline \multirow[t]{2}{*}{114} & Ultramafitite & \\
\hline & & Ultramafitite (komatiite) \\
\hline 115 & Volcanic carbonatite & \\
\hline \multirow[t]{3}{*}{116} & Plutonic rock & \\
\hline & & Plutonic rock (phaneritic) \\
\hline & & Plutonic \\
\hline 117 & Aplite & \\
\hline
\end{tabular}


Table 2.1. Lithology dictionary and indexes with alternate names present in either the State Geologic Map Compilation (SGMC, Horton, 2017; Horton and others, 2017) or Geologic Map of North America (GMNA, Garrity and Soller, 2009) databases. Dictionary based on the Geologic Map Unit Classification, version 6.1, from Johnson (2002)._- Continued

\begin{tabular}{|c|c|c|}
\hline Index & Rock type & Rock type alternates \\
\hline 118 & Porphyry & \\
\hline 119 & Lamprophyre & \\
\hline 120 & Pegmatite & \\
\hline 121 & Granitoid & \\
\hline 122 & Charnockite & \\
\hline \multirow[t]{6}{*}{123} & Alkali feldspar granite & \\
\hline & & Alkali granite (alaskite) \\
\hline & & Alkali feldspar granite \\
\hline & & Alaskite \\
\hline & & Alkali granite \\
\hline & & Leucocratic granitic \\
\hline 124 & Quartz monzodiorite & \\
\hline 125 & Monzodiorite & \\
\hline \multirow[t]{2}{*}{126} & Quartz diorite & \\
\hline & & Quartz diorite \\
\hline \multirow[t]{2}{*}{127} & Diorite & \\
\hline & & Dioritic \\
\hline 128 & Diabase & \\
\hline \multirow[t]{4}{*}{129} & Granite & \\
\hline & & Granitic \\
\hline & & Undivided granitic rocks \\
\hline & & Rapakivi granite \\
\hline 130 & Peraluminous granite & \\
\hline 131 & Metaluminous granite & \\
\hline 132 & Subaluminous granite & \\
\hline 133 & Peralkaline granite & \\
\hline 134 & Granodiorite & \\
\hline 135 & Tonalite & \\
\hline 136 & Trondhjemite & \\
\hline \multirow[t]{3}{*}{137} & Alkali feldspar syenite & \\
\hline & & Alkali syenite \\
\hline & & Quartz alkali feldspar syenite \\
\hline 138 & Quartz syenite & \\
\hline \multirow[t]{4}{*}{139} & Syenite & \\
\hline & & Syenitic \\
\hline & & Syenogranite \\
\hline & & Syenite, monzogranite \\
\hline 140 & Quartz monzonite & \\
\hline \multirow[t]{2}{*}{141} & Monzonite & \\
\hline & & Monzogranite \\
\hline
\end{tabular}


Table 2.1. Lithology dictionary and indexes with alternate names present in either the State Geologic Map Compilation (SGMC, Horton, 2017; Horton and others, 2017) or Geologic Map of North America (GMNA, Garrity and Soller, 2009) databases. Dictionary based on the Geologic Map Unit Classification, version 6.1, from Johnson (2002).-Continued

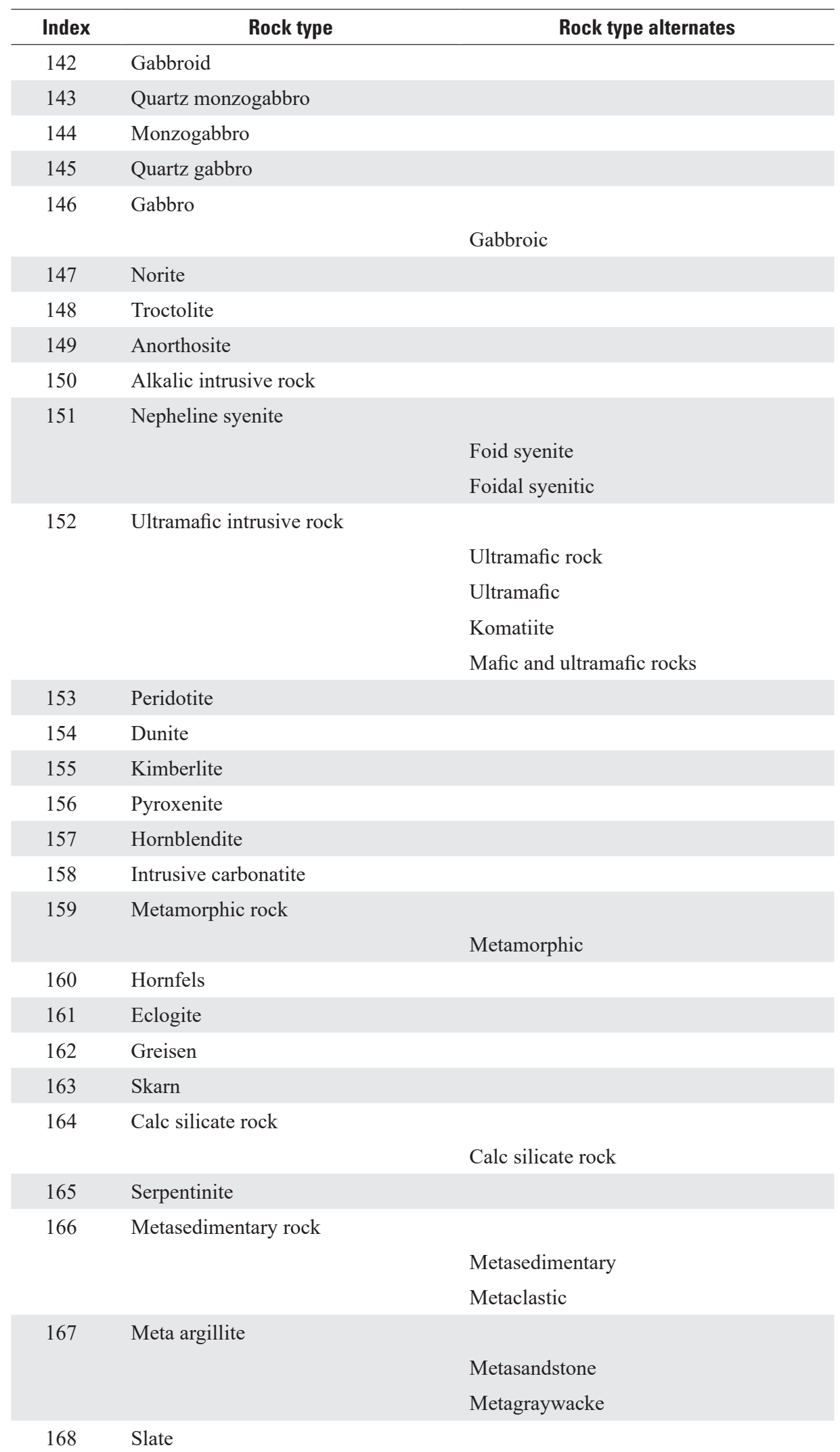


Table 2.1. Lithology dictionary and indexes with alternate names present in either the State Geologic Map Compilation (SGMC, Horton, 2017; Horton and others, 2017) or Geologic Map of North America (GMNA, Garrity and Soller, 2009) databases. Dictionary based on the Geologic Map Unit Classification, version 6.1, from Johnson (2002)._-Continued

\begin{tabular}{|c|c|c|}
\hline Index & Rock type & Rock type alternates \\
\hline & & Metasiltstone \\
\hline 169 & Quartzite & \\
\hline \multirow[t]{2}{*}{170} & Metaconglomerate & \\
\hline & & Meta conglomerate \\
\hline \multirow[t]{2}{*}{171} & Marble & \\
\hline & & Metacarbonate \\
\hline \multirow[t]{5}{*}{172} & Metavolcanic rock & \\
\hline & & Metavolcanic \\
\hline & & Metaigneous \\
\hline & & Metaintrusive \\
\hline & & Volcanic gneiss \\
\hline \multirow[t]{5}{*}{173} & Felsic metavolcanic rock & \\
\hline & & Metagranite \\
\hline & & Metaanorthosite \\
\hline & & Metatonalite \\
\hline & & Metatrondhjemite \\
\hline \multirow[t]{2}{*}{174} & Metarhyolite & \\
\hline & & Meta rhyolite \\
\hline 175 & Keratophyre & \\
\hline \multirow[t]{3}{*}{176} & Intermediate metavolcanic rock & \\
\hline & & Metadacite \\
\hline & & Metaandesite \\
\hline \multirow[t]{7}{*}{177} & Mafic metavolcanic rock & \\
\hline & & Metagabbro \\
\hline & & Metapyroxenite \\
\hline & & Metadiabase \\
\hline & & Metadiorite \\
\hline & & Metaperidotite \\
\hline & & Metadunite \\
\hline \multirow[t]{2}{*}{178} & Metabasalt & \\
\hline & & Meta basalt \\
\hline 179 & Spilite & \\
\hline 180 & Greenstone & \\
\hline 181 & Phyllite & \\
\hline 182 & Schist & \\
\hline 183 & Greenschist & \\
\hline 184 & Blueschist & \\
\hline \multirow[t]{2}{*}{185} & Mica schist & \\
\hline & & Muscovite schist \\
\hline
\end{tabular}


Table 2.1. Lithology dictionary and indexes with alternate names present in either the State Geologic Map Compilation (SGMC, Horton, 2017; Horton and others, 2017) or Geologic Map of North America (GMNA, Garrity and Soller, 2009) databases. Dictionary based on the Geologic Map Unit Classification, version 6.1, from Johnson (2002).-Continued

\begin{tabular}{|c|c|c|}
\hline Index & Rock type & Rock type alternates \\
\hline 186 & Biotite schist & \\
\hline 187 & Pelitic schist & \\
\hline 188 & Quartz feldspar schist & \\
\hline \multirow[t]{2}{*}{189} & Calc silicate schist & \\
\hline & & Calc silicate gneiss \\
\hline 190 & Amphibole schist & \\
\hline 191 & Granofels & \\
\hline 192 & Gneiss & \\
\hline 193 & Felsic gneiss & \\
\hline \multirow[t]{3}{*}{194} & Granitic gneiss & \\
\hline & & Muscovite gneiss \\
\hline & & Undivided gneissic rocks \\
\hline 195 & Biotite gneiss & \\
\hline 196 & Mafic gneiss & \\
\hline 197 & Orthogneiss & \\
\hline 198 & Paragneiss & \\
\hline 199 & Migmatite & \\
\hline \multirow[t]{2}{*}{200} & Amphibolite & \\
\hline & & Hornblende gneiss \\
\hline 201 & Granulite & \\
\hline 202 & Tectonite & \\
\hline 203 & Tectonic melange & \\
\hline \multirow[t]{3}{*}{204} & Tectonic breccia & \\
\hline & & Breccia \\
\hline & & Impact breccia \\
\hline 205 & Cataclasite & \\
\hline 206 & Phyllonite & \\
\hline 207 & Mylonite & \\
\hline 208 & Flaser gneiss & \\
\hline 209 & Augen gneiss & \\
\hline 210 & Indeterminate & \\
\hline 211 & Ice & \\
\hline 212 & Water & \\
\hline 213 & Hydrothermally altered & \\
\hline
\end{tabular}




\section{Appendix 3. Exceptions to Geologic Map Modification Rules}

The following exceptions were made to the geologic map modification rules to maximize continuity of the final maps.

1. In cases where unconsolidated sediment is on one side of the state or country border and rock is on the other, no change is made. This is done with the knowledge that where the bedrock depth map indicates that bedrock is not at the surface, the algorithm that builds the geologic profile will insert an unconsolidated sedimentary layer that will be smooth across the state or country border. This inserted unit will then be resolved upon comparison with unconsolidated units in the neighboring state or country.

2. The Idaho state map is the most recent in the State Geologic Map Compilation (SGMC), and because all the neighboring states have a smaller scale (greater detail), the default is choosing unit ages and lithology in Idaho. This increases continuity at the expense of detail in the neighboring states along Idaho's state border.

3. The State map of Colorado is preferred over neighboring states except for New Mexico simply because this choice produces the greatest continuity.

4. Several small changes are made by hand because they were not identified in the automatic algorithm. For six sedimentary rock units in the Geologic Map of North America (GMNA) map in Canada at the border with Montana and North Dakota, they are changed to the more specific SGMC sedimentary rock types. Several Miocene siltstone units in southwest Nebraska are changed to Holocene silt to match the units in Kansas, which are subsequently changed by the automatic algorithm to Quaternary sand to match units in Colorado. A Selandian sandstone in northwest Montana is changed to Paleocene claystone to match the unit in North Dakota. Lastly, one unusual change is made in Canada across the border with Montana. A strip of Devonian mafic rock was changed to Visean limestone because of the continuity in this unit across the border and no mafic rocks are identified in this part of northern Montana. 
For more information concerning the research in this report, contact the Center Director, USGS Geologic Hazards Science Center

Box 25046, Mail Stop 966

Denver, CO 80225

(303) 273-8579

Or visit Geologic Hazards Science Center website at https://geohazards.cr.usgs.gov/ 


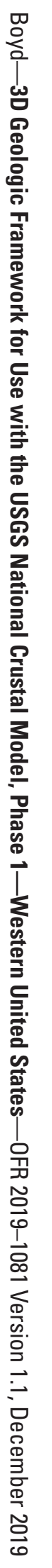

